ORNL/CF-02/15

\title{
SEMI-ANNUAL TECHNICAL PROGRESS REPORT OF RADIOISOTOPE POWER SYSTEM MATERIALS PRODUCTION AND TECHNOLOGY PROGRAM TASKS FOR APRIL 1, 2002 THROUGH SEPTEMBER 30, 2002
}

\author{
Prepared for Department of Energy \\ Office of Space and Defense Power Systems \\ under Budget and Reporting Classification \\ AF 7010200 and AF 7060000 \\ by \\ Radioisotope Power System Program \\ Metals and Ceramics Division \\ Oak Ridge National Laboratory
}

Oak Ridge National Laboratory

Oak Ridge, Tennessee 37831-6080 operated by UT-Battelle, LLC for the

U.S. Department of Energy

Contract DE-AC05-00OR22725 
This page intentionally blank 


\section{CONTENTS}

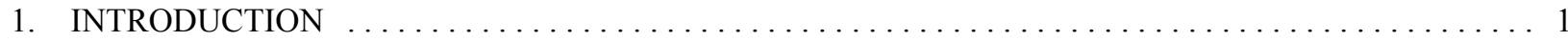

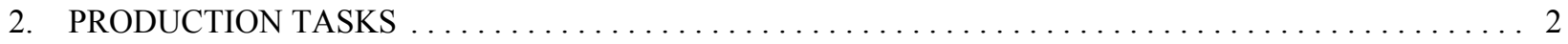

2.1 CARBON-BONDED CARBON FIBER INSULATOR SETS $\ldots \ldots \ldots \ldots \ldots \ldots \ldots \ldots \ldots \ldots \ldots \ldots 2$

2.1.1 Characterization of CBCF Sleeves Produced in Fiscal Year $2000 \ldots \ldots \ldots \ldots \ldots \ldots \ldots \ldots$

2.1.2 CBCF Sleeves and Discs Produced in Fiscal Year $2001 \ldots \ldots \ldots \ldots \ldots \ldots \ldots \ldots \ldots \ldots \ldots \ldots . \ldots \ldots$

2.1.3 CBCF Sleeves and Discs Produced in Fiscal Year $2002 \ldots \ldots \ldots \ldots \ldots \ldots \ldots \ldots \ldots \ldots \ldots . \ldots \ldots$

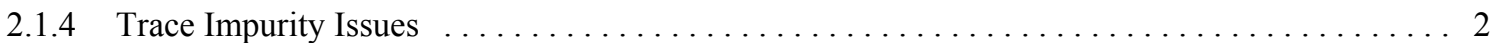

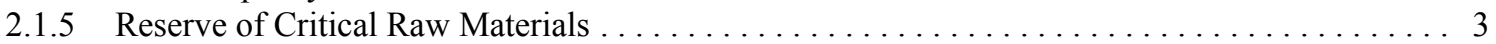

2.2 IRIDIUM-ALLOY BLANK AND FOIL PRODUCTION $\ldots \ldots \ldots \ldots \ldots \ldots \ldots \ldots \ldots \ldots \ldots$

2.2.1 Preparation of DOP-4 Iridium Alloy Foil $\ldots \ldots \ldots \ldots \ldots \ldots \ldots \ldots \ldots \ldots \ldots \ldots \ldots \ldots \ldots \ldots \ldots \ldots$

2.2.2 Preparation of DOP-26 Iridium Alloy Blanks $\ldots \ldots \ldots \ldots \ldots \ldots \ldots \ldots \ldots \ldots \ldots \ldots$

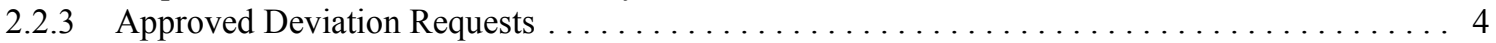

2.2.4 Production Capability Maintenance and Personnel Training $\ldots \ldots \ldots \ldots \ldots \ldots \ldots \ldots$

2.3 IRIDIUM ALLOY BLANK PRODUCTION FOR NASA $\ldots \ldots \ldots \ldots \ldots \ldots \ldots \ldots \ldots \ldots \ldots$

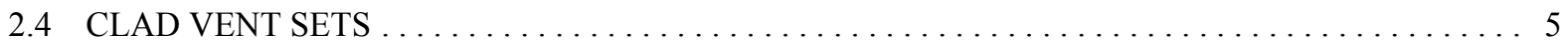

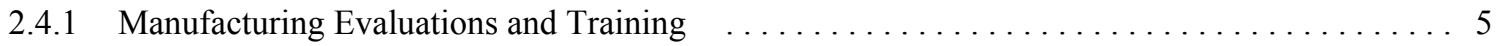

2.4.1.1 Frit Vent Assembly Sintering and Diffusion Bonding Vacuum Levels . . . . . . . . 5

2.4.1.2 Iridium Cup Forming Tooling and Blank Preheat Temperature Evaluation . . . . . . . . 6

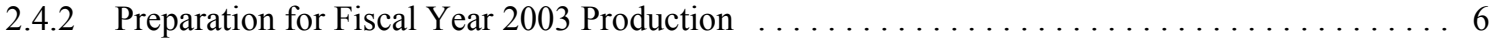

2.5 IRIDIUM POWDER INVENTORY MANAGEMENT $\ldots \ldots \ldots \ldots \ldots \ldots \ldots \ldots \ldots \ldots \ldots \ldots \ldots$

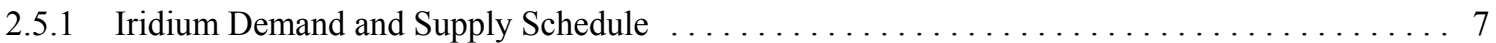

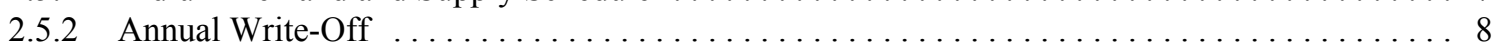

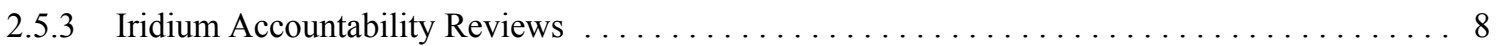

3. BASE TECHNOLOGY PROGRAM AND TECHNICAL SUPPORT ACTIVITIES $\ldots \ldots \ldots \ldots \ldots \ldots$.

3.1 TECHNICAL SUPPORT FOR THE ARPS AMTEC CELL DEVELOPMENT $\ldots \ldots \ldots \ldots \ldots \ldots 9$

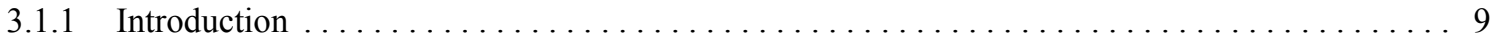

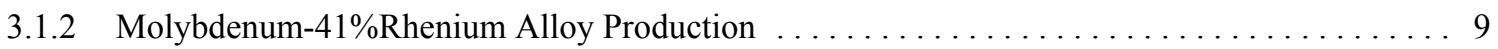

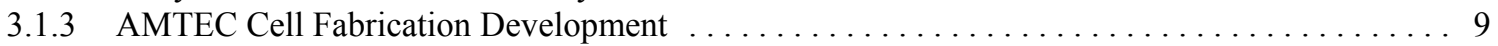

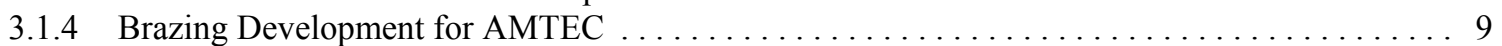

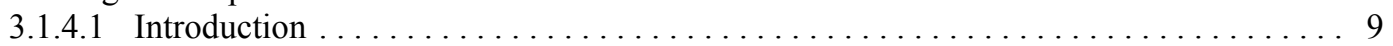

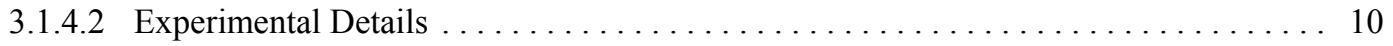

3.1 .4 .3 Results . .......................................... 11

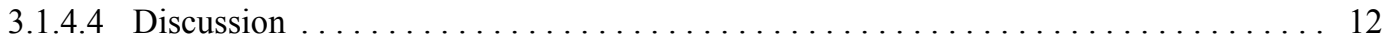

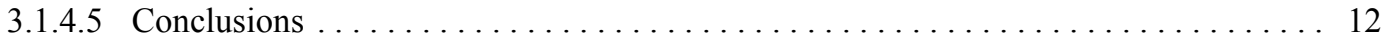

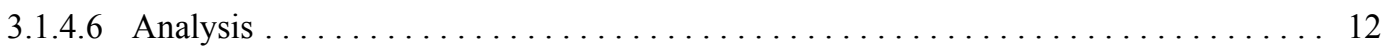

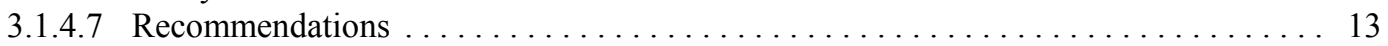

3.2 ALLOY DEVELOPMENT AND CHARACTERIZATION $\ldots \ldots \ldots \ldots \ldots \ldots \ldots \ldots \ldots \ldots \ldots$

3.2.1 Effects of Aging Up to 16 Months at 500-700EC on the Impact Ductility of Mo-41\%Re . . . 24

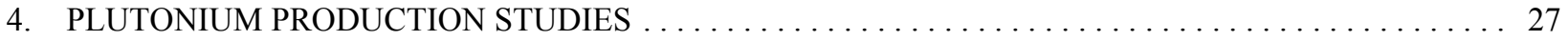

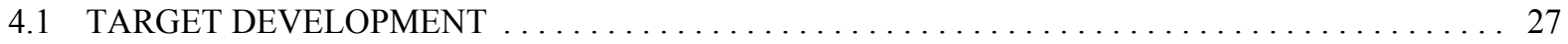

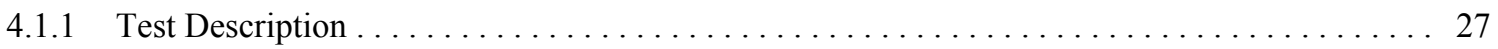

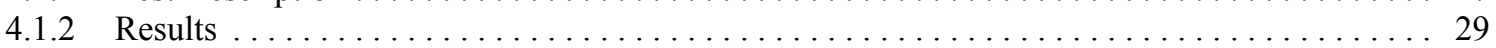

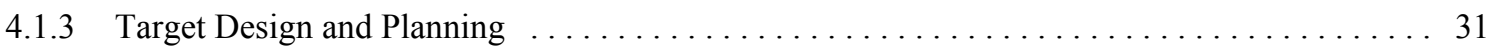

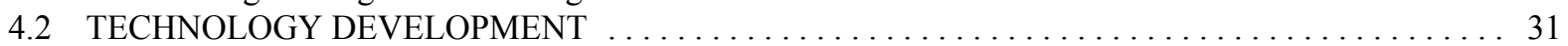

4.2.1 Baseline Plan for Neptunium Stabilization $\ldots \ldots \ldots \ldots \ldots \ldots \ldots \ldots \ldots \ldots \ldots \ldots \ldots \ldots \ldots \ldots \ldots \ldots \ldots$

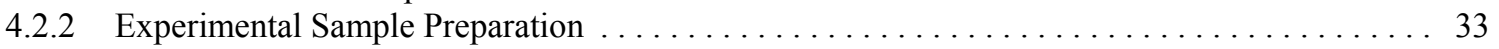

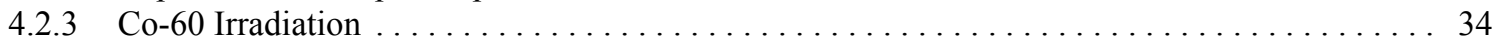

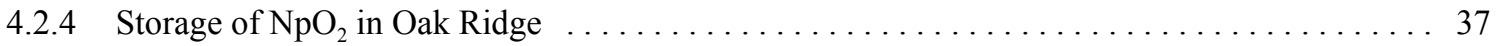


This page intentionally left blank 


\section{INTRODUCTION}

The Office of Space and Defense Power Systems of the Department of Energy (DOE) provides Radioisotope Power Systems (RPS) for applications where conventional power systems are not feasible. For example, radioisotope thermoelectric generators were supplied by the DOE to the National Aeronautics and Space Administration for deep space missions including the Cassini Mission launched in October of 1997 to study the planet Saturn. The Oak Ridge National Laboratory (ORNL) has been involved in developing materials and technology and producing components for the DOE for more than three decades. For the Cassini Mission, for example, ORNL was involved in the production of carbon-bonded carbon fiber (CBCF) insulator sets, iridium alloy blanks and foil, and clad vent sets (CVS).

This report has been divided into three sections to reflect program guidance from the Office of Space and Defense Power Systems for fiscal year (FY) 2002. The first section deals primarily with maintenance of the capability to produce flight quality (FQ) CBCF insulator sets, iridium alloy blanks and foil, and CVS. In all three cases, production maintenance is assured by the manufacture of limited quantities of FQ components. The second section deals with several technology activities to improve the manufacturing processes, characterize materials, or to develop technologies for new radioisotope power systems. The last section is dedicated to studies related to the production of ${ }^{238} \mathrm{Pu}$. 


\section{PRODUCTION TASKS}

\subsection{CARBON-BONDED CARBON FIBER INSULATOR SETS}

The goal of this effort is to maintain production capability for CBCF insulation sets. These are produced under controlled conditions and stringent quality assurance procedures to ensure compliance with material specifications at each step in the production process, from the handling of raw materials to finished parts. Dedicated facilities for CBCF production remain in the Carbon and Insulation Materials Technology Laboratory. Periodic exercise of production activities is performed to assure that the processes can be successfully executed and to verify personnel competencies and adequacy of training, equipment, and procedures. Our goals this year include the following: (1) Complete the characterization of 18 CBCF sleeves from FY 2000 production runs. (2) Complete the qualification of five CBCF sleeves and discs from FY 2001 production runs. (3) Produce and certify five new sets of CBCF sleeves and discs. (4) Take measures to enhance the reserve of critical raw materials.

\subsubsection{Characterization of CBCF Sleeves Produced in Fiscal Year 2000}

Eighteen CBCF sleeves produced in FY 2000 (E7 and E8) have been fully characterized and fifteen meet the Flight Quality specification. Full characterization of these insulators was delayed due to the rebuild of the high-vacuum outgassing furnace and the revision of procedures for sulfur analysis and the determination of thermal conductivity. These insulators were the first to be fully qualified in nearly a decade.

\subsubsection{CBCF Sleeves and Dises Produced in Fiscal Year 2001}

Eighteen CBCF sleeves produced in FY 2001 (E9 and E10) have been fully characterized. The majority of these sleeves meet the flight quality specification with the exception of trace impurity analysis. Values of $\mathrm{Ca}, \mathrm{Si}, \mathrm{Al}$, and Ti exceeded levels allowed by the specification. CBCF discs produced in FY 2001 were discontinued due to a surface imperfection issue. The source of these surface imperfections was first thought to be a fiber wetting problem associated with slurry preparation, but recent chemistry analysis suggest that entrapped impurity particles may be the cause. (See discussion of trace impurity issue below.)

\subsubsection{CBCF Sleeves and Discs Produced in Fiscal Year 2002}

Characterization of eighteen CBCF sleeves produced in FY 2002 (E11 and E12) is nearly completed. The majority of these sleeves meet the flight quality specification with the exception of trace impurity analysis. Values of $\mathrm{Ca}$ and $\mathrm{Si}$ exceeded levels allowed by the specification. CBCF Discs produced in FY 2002 were discontinued due to a recurrence of the surface imperfection issue. (See discussion of the trace impurity issue below.)

\subsubsection{Trace Impurity Issues}

The impurity content of CBCF produced in the last two years has become an issue with respect to qualifying Flight Quality insulators. This issue was only recently identified since a backlog of samples waiting outgassing in the hightemperature vacuum furnace could be analyzed for impurities in May of this year. Three samples are analyzed for impurity content by Spark Source Mass Spectroscopy for each molding run after outgassing at $1500 \mathrm{EC}$ in a vacuum of $<5 \times 10^{-5}$ torr. The specification for allowable impurity content in CBCF is:

\section{$\underline{\text { Element }} \quad \underline{\text { Maximum Acceptable Limit }}$}

$\mathrm{Cl}, \mathrm{Na}, \mathrm{K}, \mathrm{P}$

$\mathrm{Al}, \mathrm{Mg}, \mathrm{Ni}, \mathrm{Cr}, \mathrm{Cu}$

$\mathrm{B}, \mathrm{Mn}, \mathrm{Li}, \mathrm{Cd}, \mathrm{Mo}, \mathrm{Pb}, \mathrm{Zn}$

$\mathrm{Fe}, \mathrm{V}, \mathrm{Ca}, \mathrm{Ti}$

$\mathrm{S}, \mathrm{Si}$
$50 \mu \mathrm{g} / \mathrm{g}$ each

$100 \mu \mathrm{g} / \mathrm{g}$ each

$100 \mu \mathrm{g} / \mathrm{g}$ each

$200 \mu \mathrm{g} / \mathrm{g}$ each

$300 \mu \mathrm{g} / \mathrm{g}$ each

The sum of all impurities shall not exceed $1100 \mu \mathrm{g} / \mathrm{g}$ total. 
Impurity results for E9, E10, E11 and E12 sleeves exhibit impurity levels in some samples exceeding allowable levels. Excess impurities identified and their probable sources are given below.

Titanium, $\mathrm{Al}$ and $\mathrm{V}$ levels exceeding $50 \mu \mathrm{g} / \mathrm{g}$ were found in some samples. The likely source of these elements is metal particles generated by micro-cavitation at the tip of an ultrasonic horn used to aid mixing in the "Slurry Preparation Stage". Significant sample-to-sample variation in impurity levels suggests that these impurities entered the process in a particulate form. Two approaches will be considered to resolve this source of impurities. A new ultrasonic horn will be used for slurry preparation and the condition at the tip carefully monitored to avoid excessive cavitation damage. Secondly, ultrasonic energy will be introduced to the slurry preparation by an ultrasonic bath surrounding the slurry preparation vessel. Use of the second approach for flight quality insulators would require a revision of the procedure for slurry preparation.

Calcium as high as $2500 \mu \mathrm{g} / \mathrm{g}$ and $\mathrm{Si}$ as high as $510 \mu \mathrm{g} / \mathrm{g}$ were found in some samples. The likely source of these impurities is the water supply in the CBCF laboratory. Although replaceable filters are employed to screen the water used for slurry preparation, a significant length of conduit down stream from the filters maintains residual water after use. The net result is calcium and other precipitates have formed over the years. The water filtration system will be replaced with pharmaceutical grade filters and conduit. Additional precautions will be taken to assure the quality of the water. Deionized water has been used in the past to make CBCF, but problems were encountered with fiber wetting.

\subsubsection{Reserve of Critical Raw Materials}

Durez 22352 Resin is the currently specified resin used in the production of CBCF insulators. This resin was first formulated in 1962 and has been out of commercial production for nearly a decade. CBCF has been produced over the past twelve years using a quantity of Durez 22352 Resin produced in 1990. A reserve of resin sufficient for 18 molding runs is remaining. CBCF sleeves were produced in FY 2000 using the current commercial replacement for 22352 Resin. The properties of the insulation approached that of Flight Quality CBCF with a notable reduction in compressive strength. The Technology Division of Durez Corporation has recently agreed to operate their pilot plant for the production of an additional quantity of Durez 22352 from the standard starting materials. $200 \mathrm{lbs}$ of Durez 22352 Resin will be procured in FY 2003.

Nearly a ton of unchopped rayon fiber produced and qualified for CBCF is in storage at ORNL. Chopped fiber sufficient for 20 molding runs is currently available. Microfibers, Inc. of Pawtucket, RI has provided a quotation for chopping $600 \mathrm{lbs}$ of rayon fiber according to Specification MET-CER-MS-11. The total cost will be about $\$ 12,000$. This additional quantity will be sufficient for about 400 molding runs. The yield in carbonization of the rayon fiber is typically $36 \%$.

\subsection{IRIDIUM ALLOY BLANK AND FOIL PRODUCTION}

The goals for this activity are to produce flight-quality blanks and foil under full configuration control and to supply materials needed for clad vent set demonstration and maintenance activities. During the second half of FY 2002 a total of 30 blanks from the G3 ingot were stored. A total of 90 flight-quality blanks from ER10, G2 and G3 ingots were removed from storage and transferred to the CVS task. A total of $0.48 \mathrm{sq}$. $\mathrm{m}$ of foil was produced from GFR 231 and GFR 236. A total of 10 pieces of foil from ingot GFR225, with an area of $0.094 \mathrm{~m} 2$, and 16 pieces from GFR 231 and GFR 232, with total area of 0.16 sq. m, were transferred to the CVS task.

\subsubsection{Preparation of DOP-4 Iridium Alloy Foil}

The foils produced from drop-cast ingots GFR231 through GFR236 were sampled and inspected. Chemical analysis by glow discharge mass spectrograph and by combustion for carbon and oxygen content was performed at Y-12 Plant analytical laboratory. Metallographic evaluation was performed on foils in both the as-rolled and recrystallized conditions. All requirements for composition and microstructure were met. Chemical analysis for carbon and oxygen impurities in foil from DOP-4 drop castings GFR 231 through GFR 236 was completed. All materials meet the foil 
specification. Three data packages were prepared for the foils and approved by the Quality Assurance Specialist. A total of 18 pieces of foil from GFR 231 and GFR 232, with total area of 0.16 sq. m were transferred to the CVS task on August 20, 2002. The remaining foils with a total area of $0.32 \mathrm{~m}^{2}$ were stored for future use.

A total of 10 pieces of foil from ingot GFR225, with an area of $0.094 \mathrm{~m}^{2}$, were removed from storage and transferred to the CVS task on April 25, 2002.

\subsubsection{Preparation of DOP-26 Iridium Alloy Blanks}

A total of 10 billets from extruded ingot $\mathrm{G} 3$ were rolled to sheet. A total of 53 blanks were electro-discharge machined and ground. All ground blanks meet dimensional requirements. All blanks passed the ultrasonic and dye penetrant examinations. Metallographic and chemical analyses of samples for these materials were also successfully completed. Visual inspection of 37 blanks from the sheets identified as G3-7 through G3-13 was completed. A data package was prepared for a total of 30 prime blanks that have passed all inspections. A total of 7 blanks showed visual indications of inclusions, which will be reworked by sanding. There are also 16 blanks from sheets G3-13 through G3-16, which are scheduled for visual inspection during October. The data package for thirty prime blanks was reviewed by the Quality Assurance Specialist. The blanks were stored on September 26, 2002.

A total of 90 flight-quality blanks were removed from storage and transferred to the CVS task on June 13, 2002. The blanks consisted of 30 prime blanks from ER10 ingot stored in May 1998; 30 reworked blanks from ER10 ingot stored in September 1997; 27 prime blanks from ingot G3 stored in August 2001; and 3 reworked blanks from ingot G2 stored in August 2001. In addition, 40 non-flight quality blanks from the scrap ingot MS1 were transferred for use in training of CVS personnel.

\subsubsection{Approved Deviation Requests}

Three deviation requests were approved by the iridium configuration control board and distributed in accordance with the interface working agreement.

Deviation request Ir-205 covers revisions to the procedure MET-MatP-SOP-101 "Rolling Iridium DOP-26 Alloy to Sheet for Blanks from Extruded Bar." The technical changes include specific furnaces used for preheating and heattreating, lubricants for rolling, and elimination of an unnecessary in-process ultrasonic evaluation of sheets.

Deviation request Ir-206 introduces a new procedure for glow discharge mass spectroscopy of iridium materials at an outside vendor. Extensive analysis of iridium alloy reference materials and samples over a period of 18 months provided a technical basis for approval of this procedure.

Deviation request Ir-207 covers revisions to the procedure MET-MatP-SOP-85 "Reworking, Cleaning, and Inspection of Iridium Alloy Blanks". The technical changes are the discontinuation of the use of Nonconformance reports (NCR's) for blanks prior to reworking using approved procedures and the addition of a full dimensional inspection of blanks following reworking by sanding. This change brings the methods of documenting rework using approved procedures into conformity with the methods used by other tasks.

Deviation request Ir-208 makes revisions to the procedure MET-MatP-SOP-104 "Sampling and Cleaning of Iridium DOP-26 Alloy Blanks - New Process," Cutting of samples for GDMS and oxygen analysis is performed with a diamond saw instead of alumina wheel. Metallography samples may be cut with either saw. The GDMS sample size is added, and ultrasonic cleaning of samples is performed with Micro detergent instead of alcohol. Two samples are prepared for both carbon and oxygen rather than one. Separate surface GDMS and bulk thorium samples are deleted. These changes reflect the sample requirements for the above Deviation request Ir-206. All sample cleaning methods were verified as part of the technical analysis associated with that request. 


\subsubsection{Production Capability Maintenance and Personnel Training}

The iridium alloy scrap ingot MR3 was vacuum arc remelted to help maintain production capability. The starting material for MR3 consisted primarily of remelted material originating with scrap iridium materials returned from Mound Plant several years ago. A portion of the ingot was machined to produce a new starter pad for use in the vacuum arc remelt furnace. The old pad was judged no longer suitable for use because it contained cracks and surface defects, which could potentially trap contaminant particles. The remainder of the MR3 ingot was planned for extrusion as part of production maintenance efforts. The 1200 Ton extrusion press has experienced operational problems since June 2002 so that full load operation is not achieved. A representative from a company that builds and services extrusion presses visited on August 13 to consult on the repairs to the press. A retired employee familiar with the press has also begun consulting by means of email and phone conversations. The cause of the problem is the failure of the highpressure check valve to open fully during the forward extrusion process. The valve does open fully in reverse mode and for container motion. Most of the high-pressure valves and valve operators have been disassembled and inspected. These include the four ports of the main 4-way valve, the high pressure check valve itself, the high pressure throttle valve, the high-pressure cut-off valve and the operators for these valves. The high-pressure shock alleviator was also disassembled and inspected. Numerous repairs and part replacements were made. Efforts continue to determine the cause of the difficulty.

Rolling of 10 sheets of iridium alloy scrap material was completed as part of the training of a technician apprentice. This individual has been qualified for rolling of iridium alloy sheet, sampling and cleaning procedures, preparation of data packages, and rolling of foil.

A new furnace to be used for pre-sintering of iridium alloy compacts in a hydrogen atmosphere was installed.

\subsection{IRIDIUM ALLOY BLANK PRODUCTION FOR NASA}

Rolling of 17 sections from extruded bar GR4 was completed. We plan to complete machining of about 100 blanks by January 2003.

\subsection{CLAD VENT SETS}

The goal of this activity is to produce flight quality (FQ) Clad Vent Sets (CVS) for inventory, test hardware and to maintain the production capability.

\subsubsection{Manufacturing Evaluations and Training}

Manufacturing evaluations were conducted to understand better the effects of certain processing variables and to ensure that the procedure limits are sufficiently, but not overly, restrictive. Evaluations were conducted for frit vent assembly (FVA) work and cup forming.

\subsubsection{Frit Vent Assembly Sintering and Diffusion Bonding Vacuum Levels}

Test FVAs were produced using the refurbished 901 Brew vacuum furnace in building 4508. This furnace has an allmetal hot zone. A ramp-up rate of $25 \mathrm{EC} / \mathrm{min}$ was used for both the $1500 \mathrm{EC} / 1 \mathrm{~h}$ sintering and $1900 \mathrm{EC} / 2 \mathrm{~h}$ diffusion bonding operations. The sintering and diffusion bonding operations were completed with maximum soak pressures of $5 \times 10^{-6}$ and $1 \times 10^{-5}$ Torr, respectively. Earlier FVAs were produced in another furnace, the Big Brew in building $4500 \mathrm{~S}$, also with an all-metal hot zone using a ramp-up rate of $10 \mathrm{EC} / \mathrm{min}$. The sintering and diffusion bonding operations were completed with maximum soak pressures of $1 \times 10^{-5}$ and $2 \times 10^{-4}$ Torr, respectively. The normal production furnace has a graphite hot zone. The pressure is allowed to be as high as $1 \times 10^{-3} \mathrm{~T}$ Torr. Ramp-up rates have ranged from less than $10 \mathrm{EC} / \mathrm{min}$ to $25 \mathrm{EC} / \mathrm{min}$, but for production the ramp-up is standardized at $15 \mathrm{EC} / \mathrm{min}$. 
Three FVAs were sectioned metallographically to determine the adequacy of the laser weld and the diffusion bonding of the iridium powder for a metallurgical evaluation technical surveillance. 9752-05-5038 was a FQ FVA prototypic of current production components manufactured using the current production procedures and equipment. The $1500 \mathrm{EC}$ sintering and 1900EC diffusion bonding vacuum operations were done under peak pressures of $8.2 \times 10^{-4}$ and $9.2 \times 10^{-4}$ Torr, respectively. 9752-test-00DX was processed in the refurbished $901 \mathrm{Brew}$ furnace with an all-metal hot zone. The $1500 \mathrm{EC}$ sintering and $1900 \mathrm{EC}$ diffusion bonding vacuum operations were done under peak pressures of $5.3 \times 10^{-6}$ and $1.2 \times 10^{-5}$ Torr, respectively. 9752-test-00DZ was made with scrap Cassini production powder (powder lot V8366901X removed from backing discs with sintering imperfections). The $1500 \mathrm{EC}$ sintering and $1900 \mathrm{EC}$ diffusion bonding vacuum operations were done under peak pressures of $9.6 \times 10^{-4}$ and $1 \times 10^{-3}$ Torr, respectively, using the current production procedures and equipment.

The circumferential laser welds were examined and found to be uniform with no evidence of weld roll over. The metallographic examination of cross-sections showed the laser welds to be acceptable and typical of previously examined FVA welds. The iridium powder was well-bonded between the powder particles and the frit vent backing and cover discs. Comparison of these FVA cross-sections with previously examined FVAs at 200X and 500X magnification revealed them to be very similar in appearance to previous production as well as to each other. The quality of these FVAs was found to be satisfactory with no follow-up surveillance required.

In summary flow rate and manual pull testing as well as metallurgical evaluations have not shown any bonding quality differences between FVAs produced in any of the aforementioned furnaces (with graphite or metal hot zones), under any of the pressures $1 \times 10^{-3}$ to $1 \times 10^{-5}$ Torr), at any of the ramp-up rates (from $10 \mathrm{EC} / \mathrm{min}$ to $25 \mathrm{EC} / \mathrm{min}$ ). Ramp-up rates less than $10 \mathrm{EC} / \mathrm{min}$ and/or excessive dwell times above $1800 \mathrm{EC}$ for diffusion bonding were found previously to yield low flow rates.

\subsubsection{Iridium Cup Forming Tooling and Blank Preheat Temperature Evaluation}

Dimensional evaluation of the effect(s) of tooling temperatures and blank preheat temperatures during the cup first- and second-forming operations using scrap hardware was started. Initially, 8 cups were formed with the blank preheat temperatures ranging from $935 \mathrm{E}$ to $945 \mathrm{EC}$ (requirement is $925 \mathrm{E} \pm 25 \mathrm{EC}$ ) and the die temperatures to the low side $(\sim 230 \mathrm{EC})$ and the punch temperatures to the high side $(250 \mathrm{E}-270 \mathrm{EC})$ of the tooling temperature requirement of $250 \mathrm{E}$ $\pm 25 \mathrm{EC}$. Five more cups were formed with the blank preheat temperatures approximately $940 \mathrm{EC}$ and the die temperatures to the high side $(\sim 270 \mathrm{EC})$ and the punch temperatures to the low side $(\sim 230 \mathrm{EC})$. Comparison of the dimensional data for these cups as well as FY02 maintenance production cups (blank preheat 930E to 940EC, die preheat $\sim 250 \mathrm{EC}$, and punch preheat $230 \mathrm{E}$ to $240 \mathrm{EC}$ ) in the as-formed, post-sizing and post-lapping conditions did not show differences. This is very informative because it indicates that cups are dimensionally similar as long as the die and punch preheat temperatures are anywhere within the procedural requirement of $250 \mathrm{E} \pm 25 \mathrm{EC}$.

An additional, 13 cups were formed with blank preheat temperatures in the $930 \mathrm{E}$ to $940 \mathrm{EC}$ range. Five of these cups were formed with an unheated punch and a die temperature of $260 \mathrm{EC}$. Five others were formed with an unheated die and a punch temperature of $260 \mathrm{EC}$. The remaining three cups were formed with punch and die temperatures of $260 \mathrm{EC}$. These cups will be dimensionally evaluated as before, but five will be processed with extra length (height) to determine how long cups can be made with the existing blank size. The longer (or taller) cups were trimmed to lengths ranging from 0.578 " to $0.650 "$ versus the standard trim length of $0.540 "$. A new (deeper) sizing die has been made to accommodate the additional length.

\subsubsection{Preparation for Fiscal Year 2003 Production}

Ninety FQ blanks were scribed, cleaned, and welded into blank assemblies in preparation for production in FY03. These will be processed in three campaigns. The first campaign consists of 24 blanks for DOE maintenance production. The second campaign will consist of 36 blanks for National Aeronautics and Space Administration (NASA) production. The third campaign will consist of 30 blanks also for NASA. 


\subsection{IRIDIUM POWDER AND INVENTORY MANAGEMENT}

The purpose of this work is to manage an iridium inventory for all heat source contractors with emphasis on the significant quantities of iridium located at Mound Plant, Los Alamos National Laboratory (LANL), and ORNL and to maintain a no-change iridium inventory through an annual write-off of inventory and processing losses.

\subsubsection{Iridium Demand and Supply Schedule}

The annual update of the iridium demand and supply schedule is summarized in Table 1. This schedule, which is prepared for contingent planning purposes, presents a strategy to assess the availability of iridium for all improving and producing activities by projecting future demands. Using this schedule enables us to project an adequate supply to meet our current and future needs. An adequate inventory needs to be maintained due to potential future missions after Cassini. The hypothetical missions assume a need for the yearly quantities of blanks and foil in the schedule for fiscal year 2002 through fiscal year 2005.

The first part of the schedule shows the estimated production demand factors for flight-quality (FQ) blanks and foil. The schedule of produced blanks and foil represents the quantity and timing for delivery or storage at ORNL. The ingots from new material represent the quantity produced from new iridium powder to make either blanks or foil. These ingots must be produced on a timely basis to meet the lead-time requirement to produce and deliver or store the blanks and foil.

The production of the FQ blanks and foil produces recyclable iridium material that can be placed back into the production process at ORNL. A greater economic benefit is realized by using recycled material, since the need to purchase powder from an outside vendor is reduced.

Refineable iridium scrap is also generated from the production of FQ blanks, non-FQ blanks, and foil. This scrap is sent to a commercial refinery when a sufficient accumulation occurs at ORNL and funding is available for the refining.

Process losses of iridium occur during the working of the material at ORNL, Mound Plant, and LANL. Losses also occur during the refining process. These inventory losses are written-off annually.

A refining contract was planned for FY 2003. However, due to limited funding and not receiving any viable bids from refiners, this refining contract for FY 2003 was canceled. As the supply strategy portion of the table shows, there will only be enough powder at the beginning of FY 2004 to produce one ingot from new iridium powder. However, recyclable material will be available for ingot production. In addition, a test to remove thorium from scrap iridium is planned for FY 2003. Thorium removal will increase the probability of obtaining bids for scrap refining in the future.

No new purchases of iridium powder are planned at this time, as shown in the supply strategy portion of the table. The available recycle material and scrap has been considered to have been already recycled before calculating how much powder needs to be purchased. 
Table 1. Estimated Demand and Supply Schedule Shows Factors and Provides

Strategy to Ensure an Adequate Supply of Iridium Powder for Potential

Follow-On Missions After Cassini

\begin{tabular}{lcccc}
\hline & \multicolumn{4}{c}{ U. S. Government fiscal years } \\
\cline { 2 - 5 } \multicolumn{1}{c}{ Factors and strategy } & FY 2002 & FY 2003 & FY 2004 & FY 2005 \\
\hline & Production-demand factors & & \\
Produced blanks & 30 & 102 & 74 & 80 \\
Ingots from new material & 0 & 2 & 0 & 0 \\
Ingots from recyclable material & 0 & 0 & 1 & 1 \\
Produced foil (m $\left.{ }^{2}\right)$ & 0.3 & 0 & 0.3 & 0 \\
& Refining and process losses (kg) & & \\
Refining loss & 0 & 0 & 0 & 0 \\
Processing losses & 3 & 2 & 2 & 2 \\
& Supply strategy (kg) & & & \\
Beginning balance of powder & 52 & 52 & 18 & 18 \\
Receipt of refined powder & 0 & 0 & 0 & 0 \\
Receipt of purchased powder & 0 & 0 & 0 & 0 \\
\hline
\end{tabular}

$\overline{{ }^{1} \text { Fiscal year } 2005}$ beginning balance of powder will be approximately $18 \mathrm{~kg}$.

\subsubsection{Annual Write-Off}

The annual fiscal year 2002 write-off of iridium inventory was completed in June. A total of $3.4 \mathrm{~kg}$ of iridium was written off as a normal operating loss. The write-off appropriately reduced the non-fund iridium inventory. This 3.4 $\mathrm{kg}$ loss was considered a normal operating loss compared to the history of iridium losses during the past several years.

\subsubsection{Iridium Accountability Reviews}

A review at ORNL was conducted in April. The purpose of this review was to evaluate the accountability, physical inventory, and security of iridium. It was concluded that the accountability, physical inventory, and security for the iridium was in place and operating in a proper manner. Two recommendations were proposed to enhance the present accountability and physical inventory systems.

A review at LANL was conducted in August. The purpose of this review was to evaluate the accountability, physical inventory, and security of iridium. It was concluded that the accountability, physical inventory, and security for the iridium were in place and operating in a proper manner. No recommendations were necessary. 


\section{BASE TECHNOLOGY PROGRAM AND TECHNICAL SUPPORT ACTIVITIES}

\subsection{TECHNICAL SUPPORT FOR ADVANCED RADIOISOTOPE POWER SYSTEM (ARPS) AMTEC CELL DEVELOPMENT}

\subsubsection{Introduction}

The ARPS Program is developing the AMTEC converter as a possible thermal-to-electric power conversion technology in generators for outer planetary space missions being considered for NASA. These converters are fabricated from refractory metal alloys and use sodium (Na) as a working fluid with beta alumina solid electrolyte. ORNL is providing technical support to the AMTEC development program by producing Mo- $41 \%$ Re alloy ingots and processing them to various product forms, performing welding fabrication development for the converters with the electron beam (EB) welding process, and developing ceramic insulator to refractory alloy brazing alloys for the electrical feed throughs. The AMTEC Program is currently developing a "chimney design" fabricated from the Mo- $41 \% \operatorname{Re}$ alloy and demonstrating its improved conversion efficiency.

\subsubsection{Molybdenum-41\% Rhenium Alloy Production}

The Mo- $41 \%$ Re alloy production task was completed early in this reporting period. The MR7 ingot of Mo- $41 \%$ Re was extruded to rectangular bar of 1 by 2 inches. The extrusion press stalled after extruding approximately one-half of the ingot due to a mechanical failure in the press that prevented it reaching full pressure. The extruded portion of this ingot was adequate to process the required material needed to fabricate the remaining converters. This was plate material which was rolled to a thickness of 0.38 inches and shipped to AMPS. Samples of the plates were prepared for metallography to characterize the microstructure. This analysis showed the material to have a duplex grain size with locally smaller recrystallized grains.

\subsubsection{AMTEC Cell Fabrication Development}

Welding development tests were conducted to establish electron beam welding (EBW) parameters for joining an extension to the Mo-41\% Re upper converter wall to increase its length. Deep drawing of the upper wall had not been successful, so the welded extension was design to achieve the additional length desired for the SP-3 converter. The weld joint for these two cylindrical components was relatively thin and this required close control of the welding to prevent melting through the wall thickness. A successful weld was achieved with the two available test specimens. The weldment was leak tight to less than $3.9 \times 10^{-9} \mathrm{std} .-\mathrm{cc} / \mathrm{s}$ of helium.

The converter wall components for the SP-3 converter were welded at ORNL prior to the assembly and welding of the remainder of the converter. Joining was performed using the welding parameters established by the recent welding development tests. Visual examination indicated that all welds were of good quality. Subsequent leak testing at AMPS indicated the subassembly was leak tight.

The SP-3 converter was assembled at ORNL by AMPS personnel and welded with the EBW process using the established welding parameters. An artery fractured early in the process and required a replacement. A fit up problem with the condenser cap to the converter wall joint resulted in a weld defect which required repair.

\subsubsection{Brazing Development for AMTEC}

\subsubsection{Introduction}

Current designs for alkali metal thermal to electrical converter (AMTEC) cells require seals between $\alpha$ - and $\beta$-alumina ceramics and either niobium or molybdenum alloys. Forming leak-tight, reliable, robust ceramic-to-metal seals continues to be one of the more significant challenges in the development of AMTEC converters. 
Brazing is commonly used to produce ceramic-to-metal seals for AMTEC cells. An important issue for brazed seals is wetting and bonding of the braze filler metal to the ceramic component. Braze filler metals containing titanium are commonly used to produce ceramic-to-metal joints. The titanium reacts with many ceramics, including aluminas, to promote wetting and bonding, and several titanium-containing braze filler metals, often referred to as active filler metals, are commercially available. The commercial active filler metals typically are based on traditional braze filler metal systems such as copper-silver alloys or gold-nickel alloys, but they also contain small titanium additions of several wt $\%$.

The titanium-containing active braze filler metals are effective for making the seals needed for AMTEC cells. However, several issues have prevented their acceptance for this application. One is related to melting temperature of the braze filler metals and its relationship to the service temperatures of the converters. The more commonly used active braze filler metals have relatively low melting temperatures. For example, 68.8 silver- 26.7 copper- 4.5 titanium wt $\%$ has a solidus temperature of $830^{\circ} \mathrm{C}$ and 67 nickel- 33 titanium wt $\%$ has a solidus temperature of $942^{\circ} \mathrm{C}$. The maximum service temperatures experienced by ceramic-to-metal seals in AMTEC cells are in the range of $700^{\circ} \mathrm{C}$. It is believed that the proximity of converter maximum operating temperatures to the solidus temperatures of the active filler metals results in continued reaction of titanium with the alumina which degrades electrical performance.

Higher temperature active filler metals are also available, but there are cell performance concerns associated with using these braze filler metals also. One concern is that the $\beta^{\prime \prime}-\mathrm{Al}_{2} \mathrm{O}_{3}$ will degrade because of sodium vaporization during the processing required by higher temperature brazing. Another concern associated with higher temperature brazing is that metallic elements in the filler metal will be more likely to vaporize. It is thought that the vaporized metallic elements may subsequently condense on thin-walled sections of the refractory metal converter components resulting in their embrittlement.

Another critical issue associated with brazing is the compatibility of braze filler metals with sodium. Data describing the sodium compatibility of common braze filler metals is scant. However, the sodium compatibility of the common base metal alloys (copper, gold, silver, nickel) used for braze filler metals is generally not good.

\subsubsection{Experimental Details}

Several joints for a sodium exposure experiment were made of $\alpha-\mathrm{Al}_{2} \mathrm{O}_{3}$ to Mo- $41 \%$ Re sheet by vacuum furnace brazing with an experimental filler metal of nominal composition: 48 titanium- 48 zirconium- 4 beryllium wt $\%$ (referred to as TiZrBe). The brazing temperature used was either $1170^{\circ} \mathrm{C}$ or $1180^{\circ} \mathrm{C}$. Visual examination of the joints showed that filleting and overall appearance was good. Examination at 10-30X magnification indicated that the joints were free of visible defects.

Five double-wall capsules were fabricated for sodium exposure testing. The sodium containment capsules were made from Mo tubing, 25.5-mm-diameter x 0.8-mm-wall. End caps for the Mo capsules were machined from Mo bar. The end caps were 2.5 -mm-thick, and they were made to slide into the Mo tubing with an interference fit. One end of each capsule was closed by electron beam welding the end cap to the tube. The unwelded end caps were also fitted with loops made from Mo wire for holding specimens during the exposure experiments, Fig. 1 (top). One joint from each brazing temperature was connected to the unwelded end cap with Mo wire as shown in Fig. 1 (bottom). Sodium was loaded into the Mo capsules and the end caps with braze joints attached were welded to seal the Mo capsules.

The Mo capsules were then encapsulated in stainless steel capsules of similar configuration but larger dimensions. The stainless steel capsules were machined from tubing, and a cap was welded on one end of each. The Na-filled Mo capsules were placed into the stainless steel capsules. Graphite spacers were machined for maintaining the position of the Mo capsules inside of the stainless steel capsules. The stainless steel capsules were welded shut, marked for identification purposes, Fig. 2 (top), and placed into an air muffle furnace preset at $500^{\circ} \mathrm{C}$, Fig. 2 (bottom). After holding for an hour, one capsule was inverted so that its braze joint specimens were submerged in the liquid Na rather than exposed to vapor. The sodium capsules were held at $500^{\circ} \mathrm{C}$ for $1000 \mathrm{~h}$. The capsules were cut open after the exposure, and the braze joints were submerged in ethyl alcohol to dissolve away any metallic $\mathrm{Na}$. All four of the braze joint specimens were weighed before encapsulation and no significant weight changes were measured as a result of the $\mathrm{Na}$ exposure. One of the braze joints made at $1170^{\circ} \mathrm{C}$ fell apart during $\mathrm{Na}$ removal, and the other one fell apart during 
sectioning for metallographic examination. Both of the joints made at $1180^{\circ} \mathrm{C}$ were successfully sectioned and specimens were prepared for metallographic examination. The specimen were examined optically and in a scanning electron microscope (SEM). Microchemical analyses by energy dispersive spectroscopy (EDS) were also conducted in the SEM.

\subsubsection{Results}

The overall appearance of two braze joints is compared in Fig. 3. The specimens were etched in a solution of water + $30 \mathrm{ml} \mathrm{HNO}{ }_{3}+10 \mathrm{ml} \mathrm{HF}$ to reveal the microstructures in the braze joints. To serve as a reference, Fig. 3a shows one of the joints made originally during the course of initial evaluation of the TiZrBe filler metal. Figure $3 \mathrm{~b}$ shows a joint after the $\mathrm{Na}$ exposure. The volume of filler metal is not identical in the two joints, but they are otherwise nearly identical in appearance. A notable difference is that the joint in Fig. $3 \mathrm{~b}$ contains several prominent cracks in the a- $\mathrm{Al}_{2} \mathrm{O}_{3}$ that emanate from the edges of the joint and travel in a semi-circular orientation below the joint. Details of these cracks are shown in Fig. 4. Figure 4a shows that a large crack also developed approximately parallel to the $\mathrm{Al}_{2} \mathrm{O}_{3}$ surface in the braze filler metal layer. Figure $4 \mathrm{~b}$ shows a crack normal to the $\mathrm{Al}_{2} \mathrm{O}_{3}$ surface in the braze filler metal in the fillet of the joint.

More details of the joints are shown in Fig. 5. The contrast of these images is not identical, but the overall appearance of the microstructures in the braze filler metals is essentially the same. In the fillet regions of the joints, the filler metal appears to have undergone phase separation during the brazing and solidification process. This is evidenced by the rather thick layer at the $\mathrm{Al}_{2} \mathrm{O}_{3}$ surface. However, the details of the filler metal solidification did not adversely affect joint integrity. Microchemical analyses taken from the joint in Fig. 5b are presented in Fig. 6. Areas, approximately of the sizes shown in Fig. $5 \mathrm{~b}$ were scanned for the analyses so that the data represent an average chemical composition within the scanned area. The top spectrum (Location \#1) was taken in the MoRe sheet as a reference. As expected, the only elements detected in the sheet are Mo and Re. The middle data (Location \#2) are from the relatively thick layer nearest the $\alpha-\mathrm{Al}_{2} \mathrm{O}_{3}$ surface. Titanium, $\mathrm{Zr}$ and $\mathrm{Re}$ were detected in this layer, but it is enriched in Ti. The spectrum from main part of the fillet (Location \#3) is shown at the bottom of Fig. 6. Rhenium is also present there, but this region is relatively enriched in Zr. Molybdenum may also be present at these locations, but interference between peaks for Mo and $\mathrm{Zr}$, and the relatively high $\mathrm{Zr}$ concentrations prevent the presence of Mo in the filler metal from being unambiguously revealed. Even though the TiZrBe filler metal contains $4 \mathrm{wt} \% \mathrm{Be}$, this element could not be detected by this EDS analysis system because Be x-rays are absorbed in the Be window used to shield the detector.

The microstructures within the joint regions are compared in Fig. 7. Both images show that the bulk of the filler metal layer is composed of two phases, and that a thin reaction layer formed on the $\alpha-\mathrm{Al}_{2} \mathrm{O}_{3}$ surface during brazing. Microchemical analyses in these regions were done using point probes. The EDS data taken from the MoRe and the $\alpha-\mathrm{Al}_{2} \mathrm{O}_{3}$ near the brazed interfaces are shown in Fig. 8. There is no indication of transport of filler metal elements into either of these base materials, although Be transport would not be detected. The EDS spectra of the major phases in the braze filler metal layer are shown in Fig. 9. The phase of lighter contrast is enriched in $\mathrm{Zr}$ (Location \#5), while that of darker contrast is enriched in $\mathrm{Ti}$ (Location \#6). Both of these phases also contain Mo and Re, confirming that some dissolution of the MoRe sheet into the filler metal alloy occurred. The phase of darkest contrast that occurred at the interface between the $\mathrm{Al}_{2} \mathrm{O}_{3}$ and the filler metal appears to be an oxide phase. The only element appearing in EDS spectra for this phase is $\mathrm{O}$. Its dark contrast indicates that the average atomic weight of this phase is the lowest of any phase imaged, even lower than $\mathrm{Al}_{2} \mathrm{O}_{3}$. Based on these observations it is likely that this interface reaction layer is $\mathrm{BeO}$. The horizontal feature in Fig. $7 \mathrm{~b}$ through the braze filler metal layer is the crack previously noted in Fig. 4.

All of the specimens used for microchemical analysis by EDS in the SEM were coated with carbon. Consequently, all of the spectra shown in Figs. 6, 8, and 9 have small peaks near $0 \mathrm{eV}$ that originate from the carbon coatings.

It should be possible to detect $\mathrm{Na}$ with this microchemical analysis system, but none was found at any location either within the braze filler metal or at its surfaces that were exposed to liquid $\mathrm{Na}$. The edge of the filler metal fillet at the $\mathrm{Al}_{2} \mathrm{O}_{3}$ surface is shown in Fig. 10. The crack emanating from the junction of the filler metal with the $\mathrm{Al}_{2} \mathrm{O}_{3}$ is clearly visible extending into the ceramic. However, there is no indication of $\mathrm{Na}$ attack or wastage at the filler metal surface or along the interface of the filler metal with the $\mathrm{Al}_{2} \mathrm{O}_{3}$. 


\subsubsection{Discussion}

During the course of these experiments many joints of $\alpha-\mathrm{Al}_{2} \mathrm{O}_{3}$ to MoRe were vacuum brazed using the TiZrBe filler metal. This filler metal gave consistent results in terms of visual appearance. Also, no problems were encountered in routine handling of the joints, indicating they had some level of useable strength. The joints made for the Na exposure experiment were handled extensively prior to the actual exposure and they appeared to survive this without problems. After the Na exposure, the joints were much more fragile.

The location and orientation of cracking in the $\alpha-\mathrm{Al}_{2} \mathrm{O}_{3}$ after exposure, illustrated in Fig. 5b, are typical of the effects of residual stresses in ceramic-to-metal joints. It is possible that the existence of residual stress fields could have promoted localized attack by $\mathrm{Na}$, similar to stress-corrosion cracking phenomena observed in metals under more conventional conditions. It is also possible that cracking of the alumina could have occurred due only to the action of heating the joints to $500^{\circ} \mathrm{C}$, and holding them there for an extended period. Based on the results to date, it cannot be established unequivocally whether $\mathrm{Na}$ exposure was directly responsible for deterioration of the mechanical integrity of the joints.

No significant changes to the microstructure of the joints were produced by the Na exposure. Examination of exposed surfaces in the SEM suggested that no attack of either the TiZrBe filler metal, the MoRe sheet, or the $\alpha-\mathrm{Al}_{2} \mathrm{O}_{3}$ occurred. No mass transport of Na into any of these materials was detected by microchemical analysis by EDS. It is possible however that $\mathrm{Na}$ was present in these locations at concentrations below the detection limit of the EDS system, typically $<1 \mathrm{wt} \%$. Analysis by alternate techniques will be required to detect $\mathrm{Na}$ at lower concentrations.

\subsubsection{Conclusions}

1. The TiZrBe experimental braze filler metal alloy, $48 \mathrm{Ti}-48 \mathrm{Zr}-4 \mathrm{Be} \mathrm{wt} \%$, appears capable of making strong joints of $\alpha-\mathrm{Al}_{2} \mathrm{O}_{3}$ to MoRe. The alloy reacts with $\alpha-\mathrm{Al}_{2} \mathrm{O}_{3}$ during brazing to form an oxide reaction layer, the exact chemical composition of which could not be determined.

2. Mass transport between the braze filler metal alloy and the $\alpha-\mathrm{Al}_{2} \mathrm{O}_{3}$ was minimal, excluding Be which was not detectable by the electron probe system used for the analysis. Therefore, contamination of the $\mathrm{Al}_{2} \mathrm{O}_{3}$ by metallic elements other than $\mathrm{Be}$ is expected to be negligible.

3. Limited dissolution of the MoRe sheet into the braze filler metal layer occurred.

4. The TiZrBe alloy appears resistant to liquid $\mathrm{Na}$ for an exposure of $1000 \mathrm{~h}$ at $500^{\circ} \mathrm{C}$.

\subsubsection{Analysis}

1. The oxide, $\mathrm{BeO}$, is thermodynamically more stable than $\mathrm{Al}_{2} \mathrm{O}_{3}$. Therefore, $\mathrm{Be}$ is capable of reducing $\mathrm{Al}_{2} \mathrm{O}_{3}$ to produce $\mathrm{BeO}$ and $\mathrm{Al}$. Because of this, and because $\mathrm{Be}$ was not detected by the electron probe analysis, it is likely that the oxide particles that formed at the $\mathrm{Al}_{2} \mathrm{O}_{3}$ /filler metal interface were $\mathrm{BeO}$. Reduction of the $\mathrm{Al}_{2} \mathrm{O}_{3}$ by $\mathrm{Be}$ is likely to release a very small amount of $\mathrm{Al}$ to dissolve in or to react with the braze filler metal alloy.

2. None of the elements, $\mathrm{Mo}, \mathrm{Re}, \mathrm{Ti}$, or $\mathrm{Zr}$ were detected in the $\mathrm{Al}_{2} \mathrm{O}_{3}$. Therefore, it is unlikely that these elements would be major contaminants to $\beta-\mathrm{Al}_{2} \mathrm{O}_{3}$. Because $\mathrm{Be}$ is capable of reducing $\mathrm{Al}_{2} \mathrm{O}_{3}$ to form $\mathrm{BeO}$, it is also unlikely that $\mathrm{Be}$ would be a major contaminant in $\mathrm{Al}_{2} \mathrm{O}_{3}$.

3. Some reaction or mass transport between the TiZrBe and the MoRe is desirable because it promotes good bonding. Excess interaction during the brazing operation is undesirable because it can diminish the joint integrity.

4. There was no indication that any reaction layers formed by exposure on the filler metal alloy to the liquid Na. There was no indication that Na diffused into the filler metal alloy. 
5. The observation of extensive cracking of the $\alpha-\mathrm{Al}_{2} \mathrm{O}_{3}$ after the $\mathrm{Na}$ exposure was unexpected because the phenomenon was not observed in the specimens used for initial evaluation of the braze filler metal alloy or for those used to establish the brazing conditions. The cracking of the $\mathrm{Al}_{2} \mathrm{O}_{3}$ after $\mathrm{Na}$ exposure suggests that the $\mathrm{Na}$ may contribute to the cracking. However, the cracking could have resulted exclusively from residual stresses.

\subsubsection{Recommendations}

The TiZrBe alloy, or another composition in this alloy system, appears to have the potential of satisfying the constraints of AMTEC fabrication. Namely, the alloy can be used for brazing at a relatively low temperature, $\sim 1200^{\circ} \mathrm{C}$. It appears to bond well to $\mathrm{Al}_{2} \mathrm{O}_{3}$ and to the MoRe alloy. It appears resistant to Na exposure. Mass transport of filler metal elements into the $\mathrm{Al}_{2} \mathrm{O}_{3}$ is likely to be minimal.

Because cracking will compromise joint integrity, it is important to determine its source and to find a way of eliminating it. Several experiments should be considered for the $\mathrm{MoRe}-\mathrm{Al}_{2} \mathrm{O}_{3}$ braze joints:

1. The $\mathrm{Na}$ exposure experiment should be repeated. In addition, identical braze joints should be exposed to the same thermal treatment of $500^{\circ} \mathrm{C}$ for $1000 \mathrm{~h}$. This would help distinguish between the effects of Na exposure and thermal exposure on joint integrity.

2. It is likely that the braze filler metal has a thermal expansion coefficient that is higher than that of the $\alpha-\mathrm{Al}_{2} \mathrm{O}_{3}$. The coefficients of thermal expansion for $\mathrm{Al}_{2} \mathrm{O}_{3}, \mathrm{Be}, \mathrm{Ti}$ and $\mathrm{Zr}$ are shown in Fig. 11. The composition of the braze filler metal alloy in at $\%$ is $51 \mathrm{Ti}-27 \mathrm{Zr}-22 \mathrm{Be}$. Inspection of Fig. 11 shows that using the composition in at $\%$ and assuming the rule of mixtures results in a coefficient of thermal expansion for the braze filler metal alloy that is higher than that of $\mathrm{Al}_{2} \mathrm{O}_{3}$. The high assumed coefficient of thermal expansion for the braze filler metal and its relatively large volume in the braze joints would tend to cause the type of cracking observed after $\mathrm{Na}$ exposure.

3. Based on this analysis of the braze filler metal thermal expansion it would be reasonable to produce some joints where less filler metal is used. It would also be reasonable to determine the variation of melting temperature with amount of $\mathrm{Be}$ in the alloy. This could reduce the Be concentration of the filler metal, possibly reducing its coefficient of thermal expansion. A similar approach would be to evaluate whether another alloy system, such as Mo-Ti-Be, could yield an acceptable braze filler metal alloy for this application. 

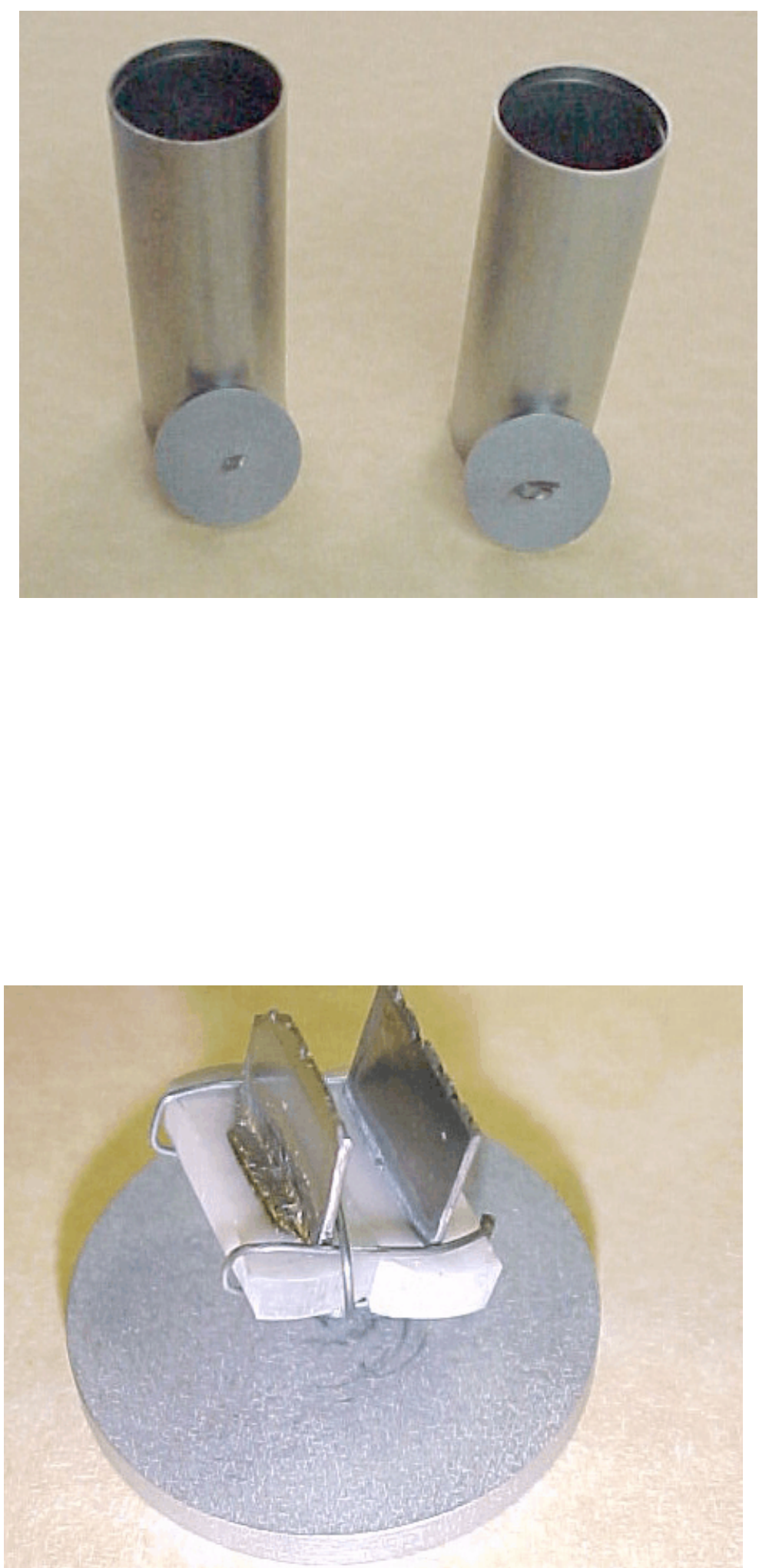

Fig. 1. Top photograph shows the Mo capsules used to contain the Na exposure experiment for joints of MoRe sheet brazed to $\alpha$ $\mathrm{Al}_{2} \mathrm{O}_{3}$ with TiZrBe filler metal. Bottom photograph shows two braze joints attached to a Mo capsule lid with Mo wire. 

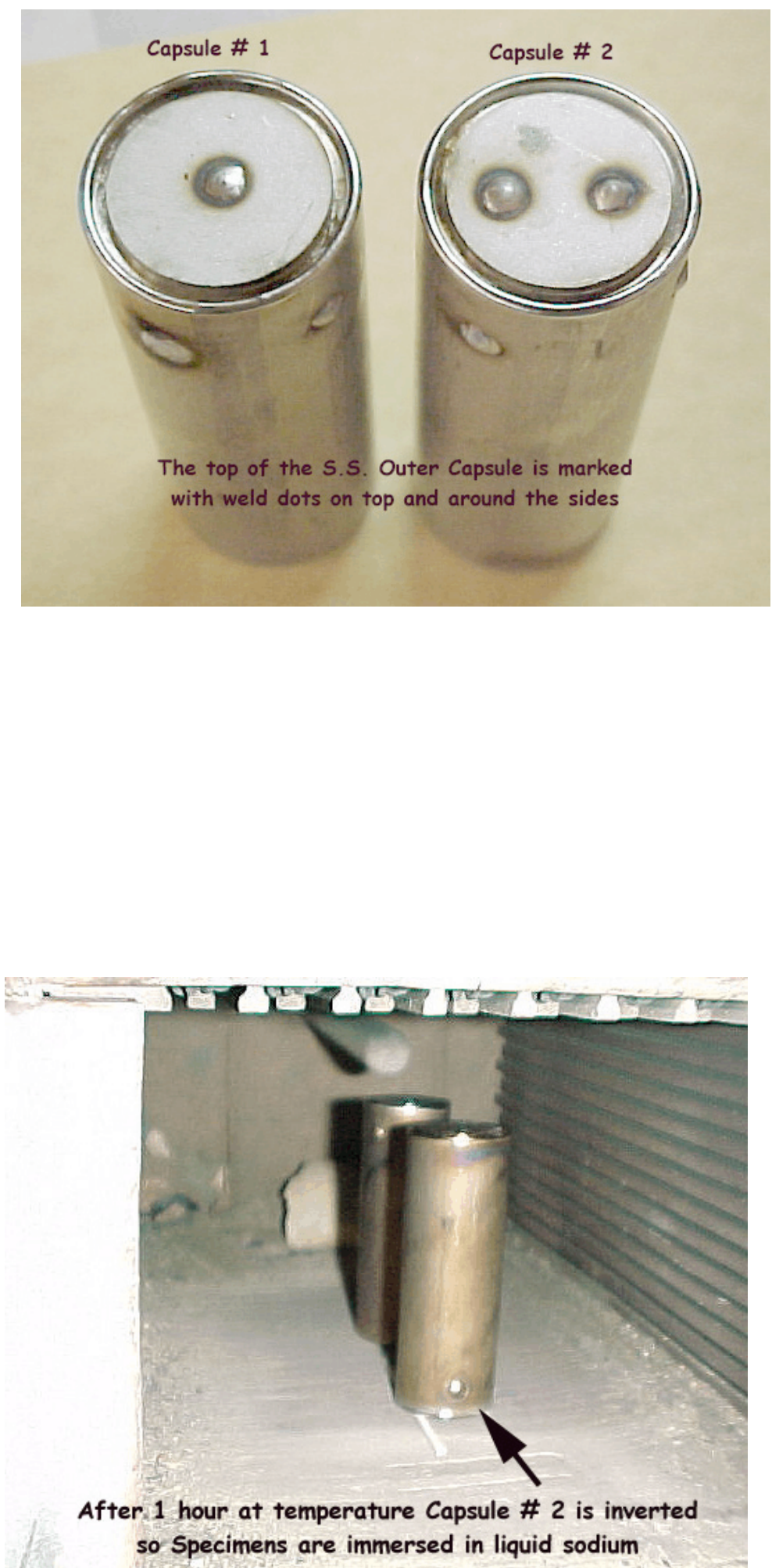

Fig. 2. Top photograph shows the stainless steel capsules that contained the Mo capsules that were charged with $\mathrm{Na}$ for exposure of the braze joints. Bottom photograph shows the complete assemblies as they were loaded into a muffle furnace at $500^{\circ} \mathrm{C}$ for the 1000 hour exposure. 


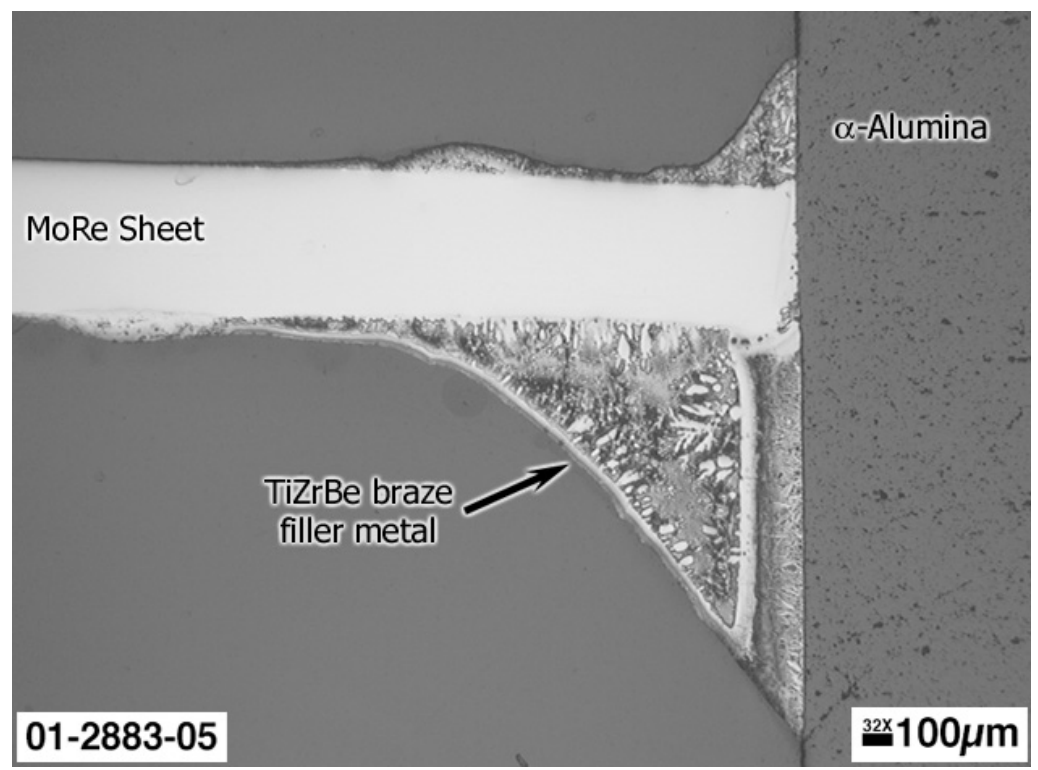

(a)

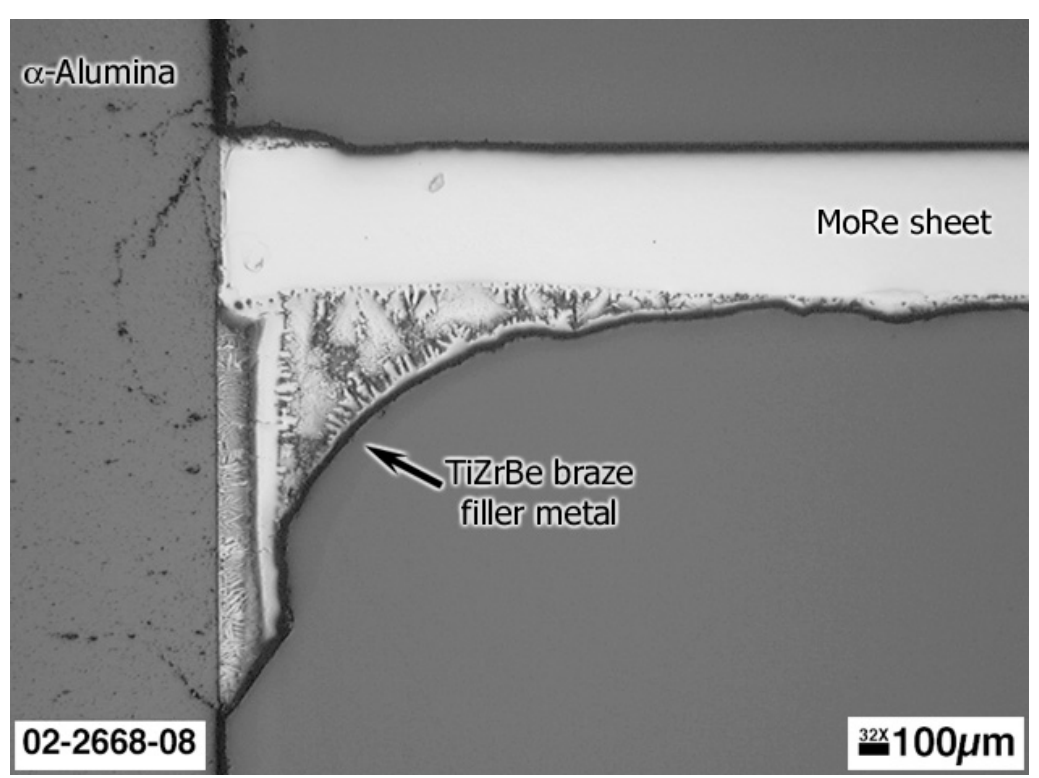

Fig. 3. Optical micrographs of MoRe brazed to $\alpha-\mathrm{Al}_{2} \mathrm{O}_{3}$ with TiZrBe filler metal in the as-brazed, unexposed condition (a), and after exposure to liquid $\mathrm{Na}$ at $500^{\circ} \mathrm{C}$ for $1000 \mathrm{~h}(\mathrm{~b})$. 
(a)

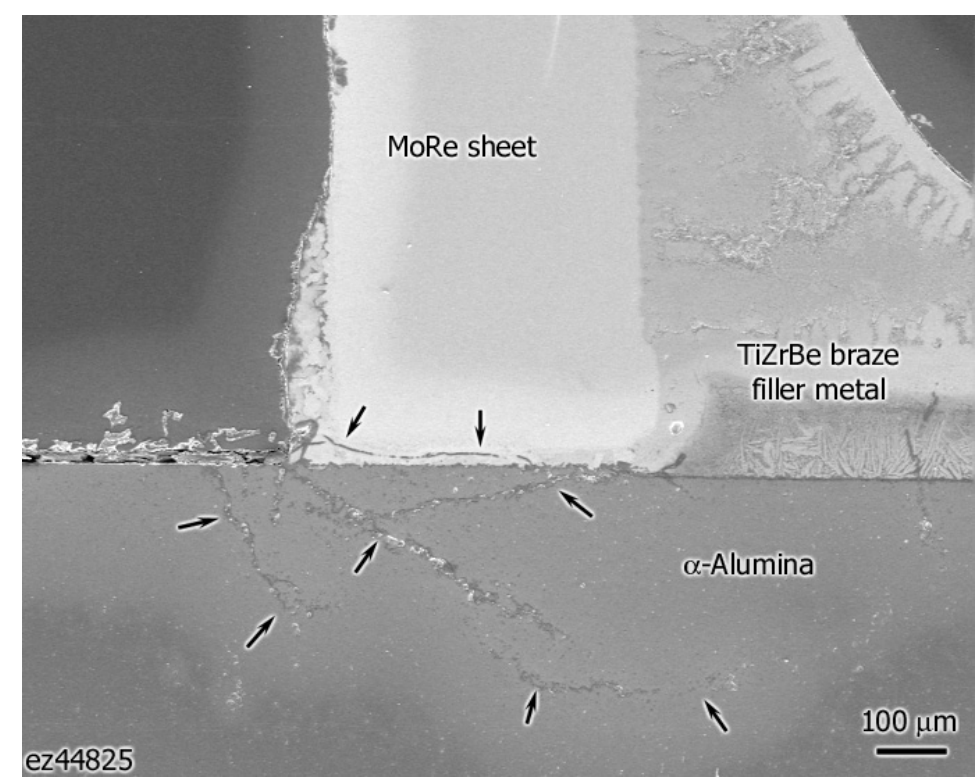

(b)

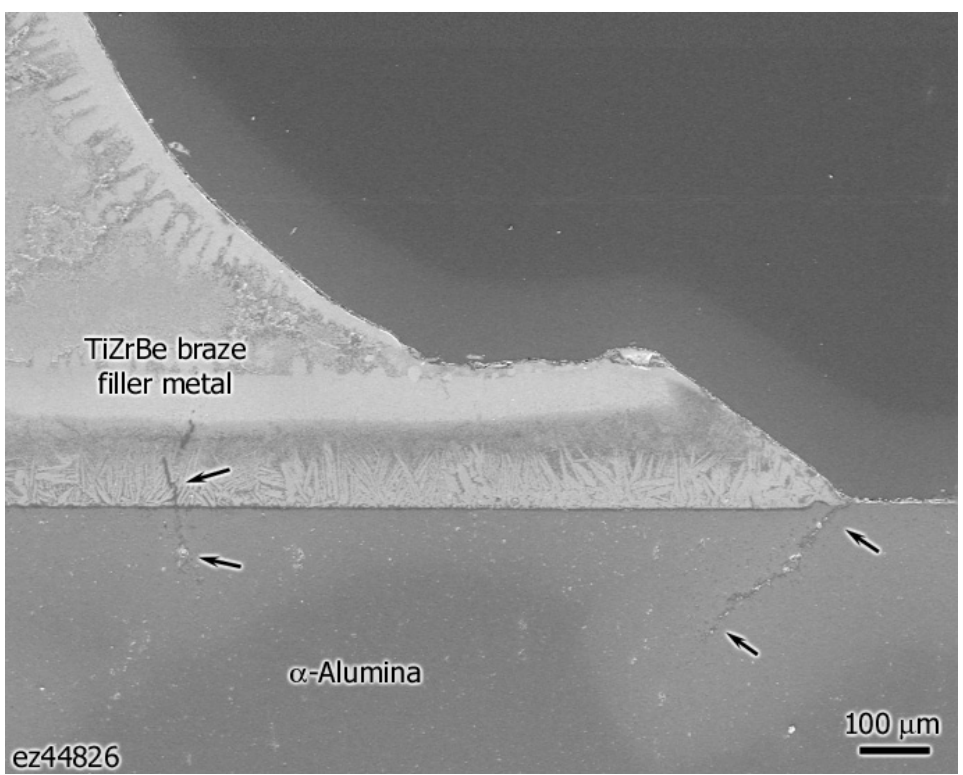

Fig. 4. SEM micrographs of the braze joint from liquid $\mathrm{Na}$ exposure showing extensive cracking of the $\alpha-\mathrm{Al}_{2} \mathrm{O}_{3}$ beneath the brazed region. 


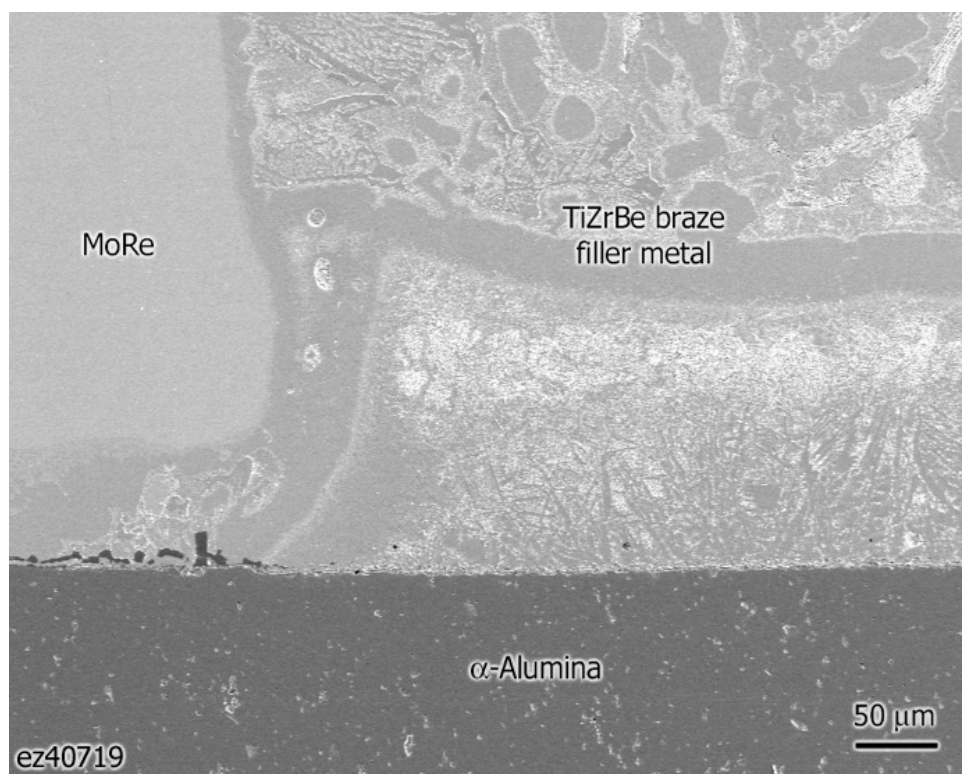

(a)

(b)

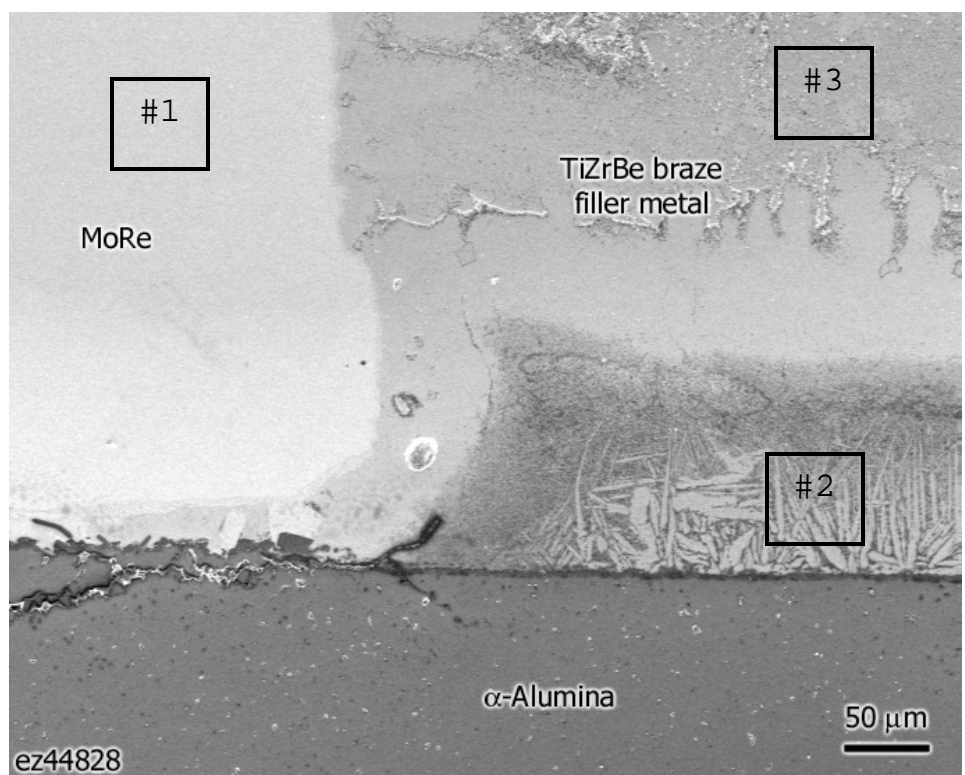

Fig. 5. SEM micrographs comparing the braze joint microstructure in the as-brazed condition (a) and after exposure to liquid $\mathrm{Na}$ (b). The numbered boxes in the bottom micrograph indicate areas used for microchemical analysis data shown in Fig. 6. 


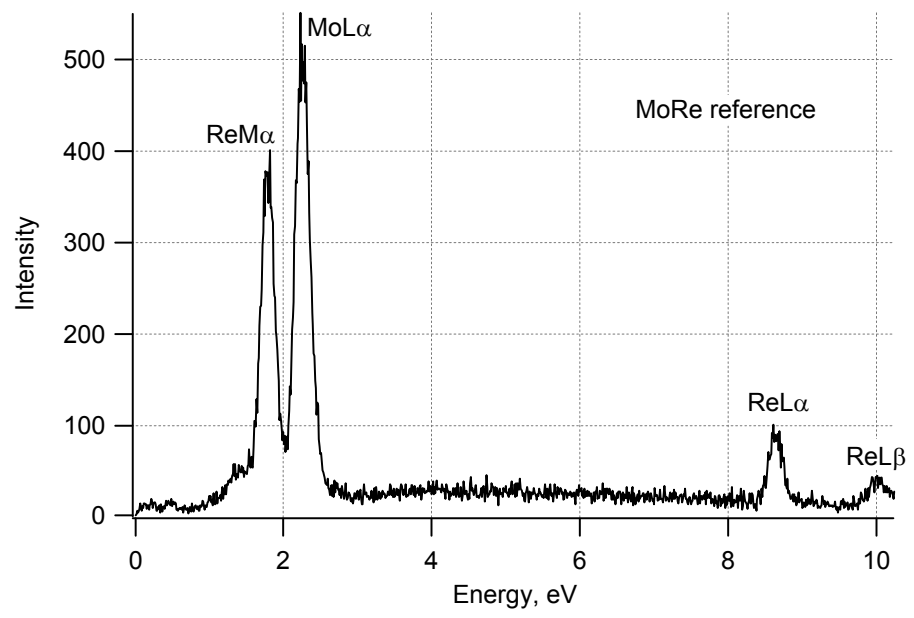

(a)

(b)

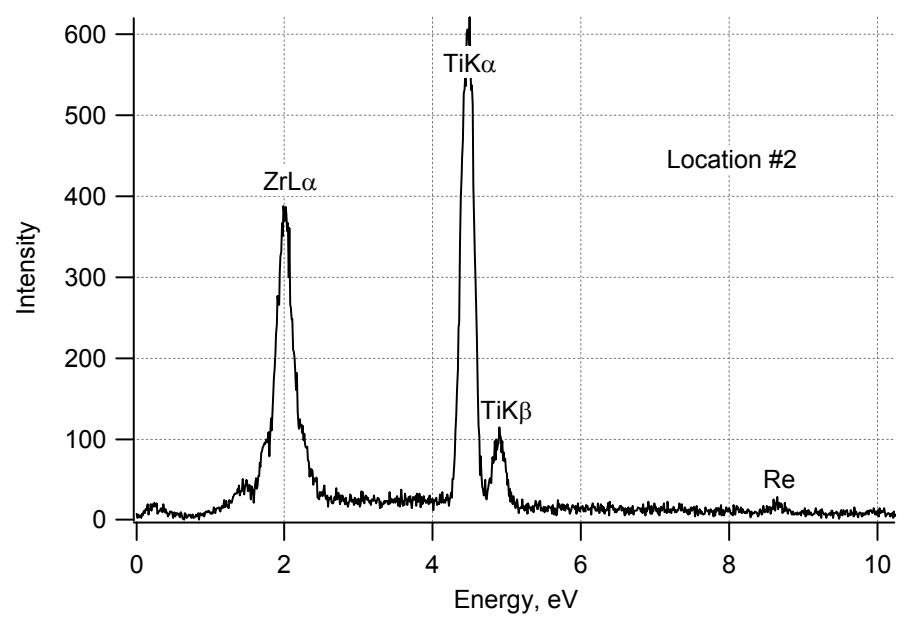

(c)

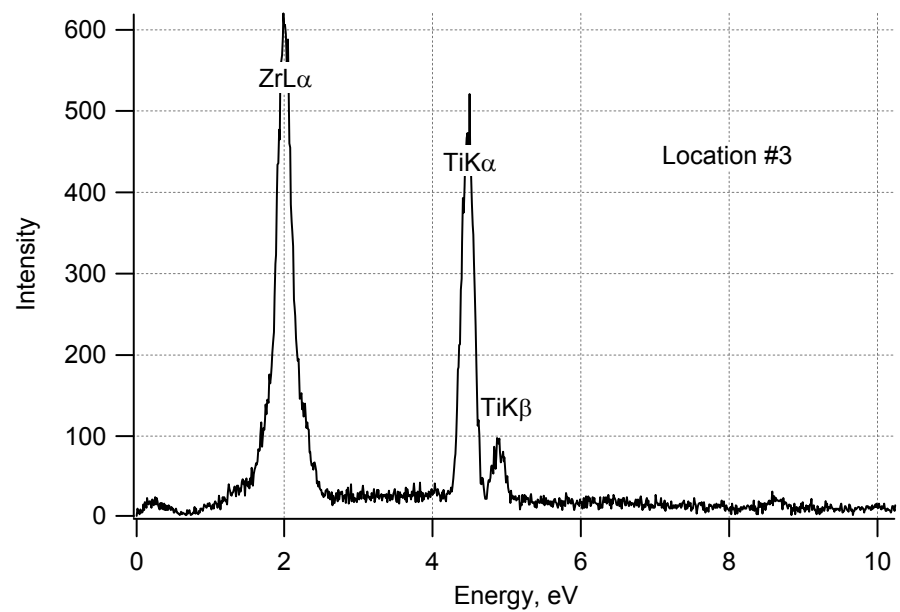

Fig. 6. EDS spectra taken in the SEM from the MoRe sheet (Location \#1 in Fig. 5b) and from the fillet of the TiZrBe braze filler metal (Locations \#2 \& \#3). 


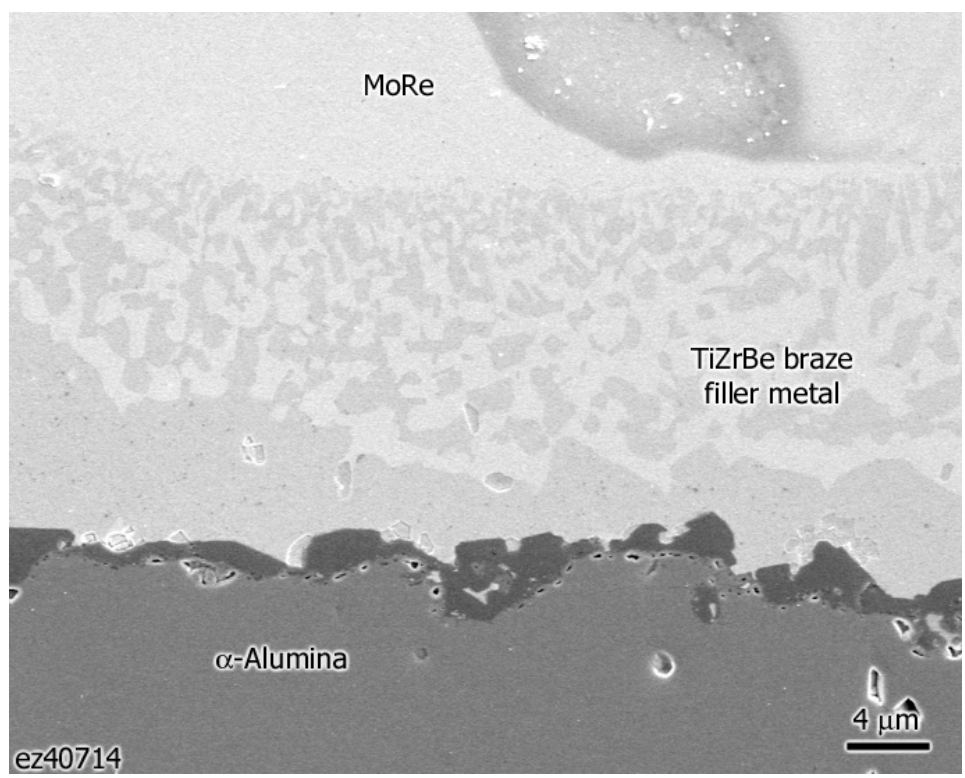

(a)

(b)

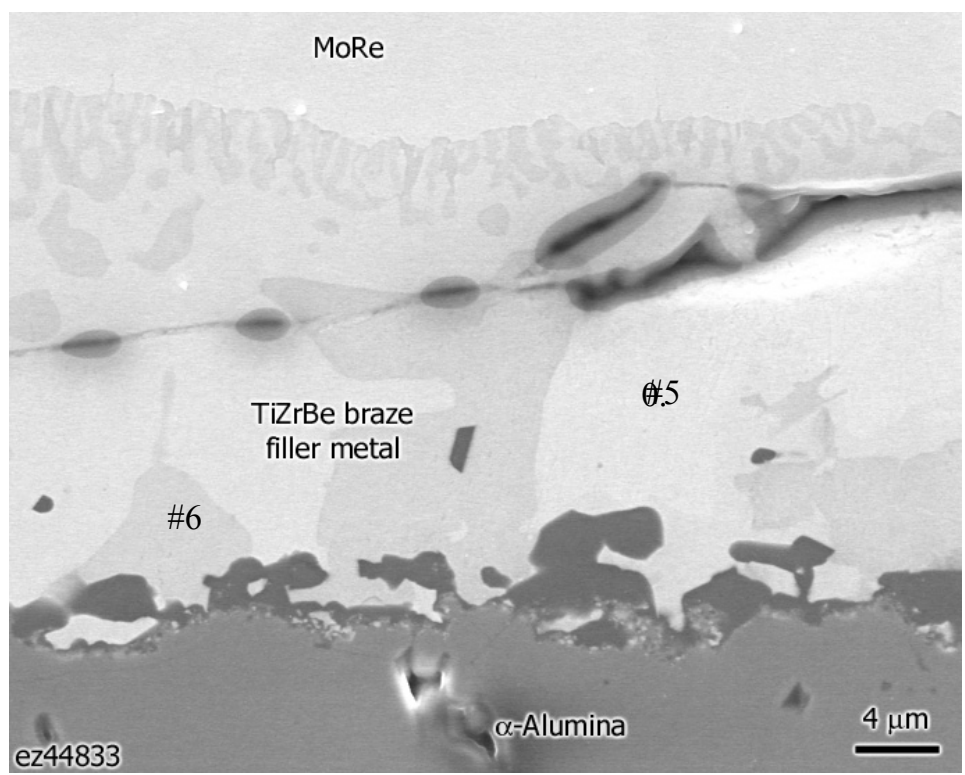

Fig. 7. SEM micrographs of the braze filler metal layer in the as-brazed condition (a), and after exposure to liquid $\mathrm{Na}$ (b). EDS spectra associated with points \#5 \& \#6 are shown in Fig. 9. 


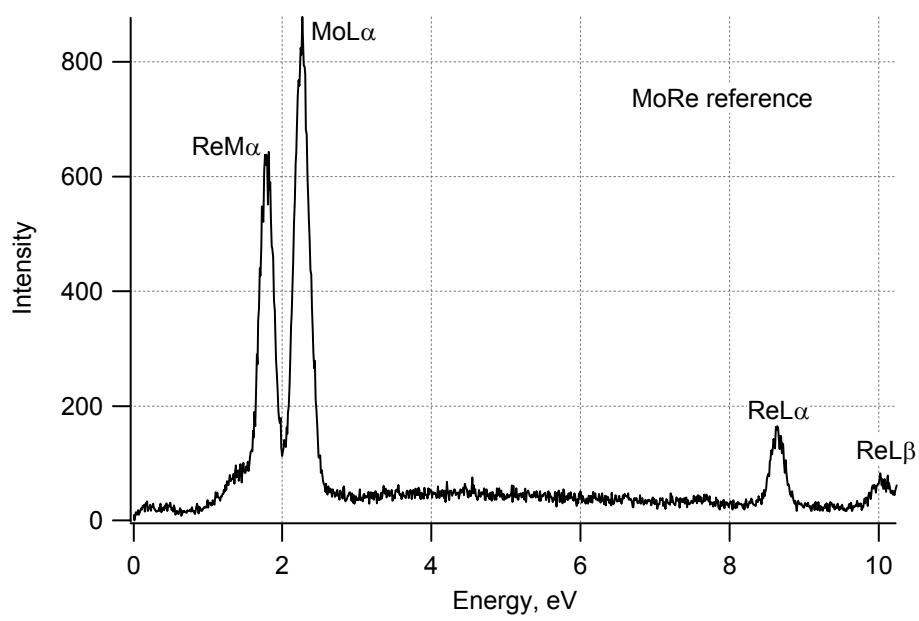

(a)

(b)

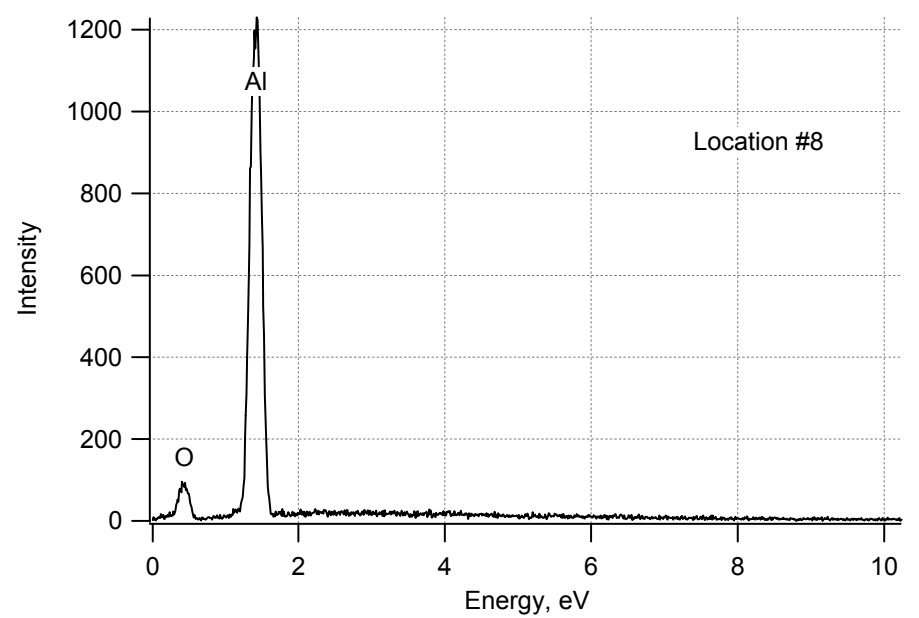

Fig. 8. EDS spectra taken from near the brazed interfaces in the MoRe sheet (a) and in the $\alpha-\mathrm{Al}_{2} \mathrm{O}_{3}(\mathrm{~b})$. 


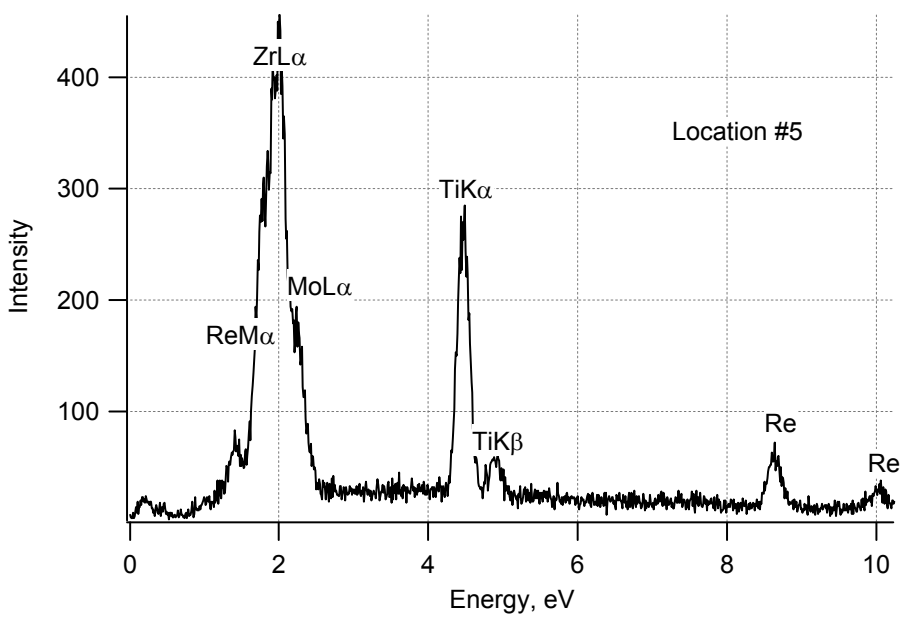

(a)

(b)

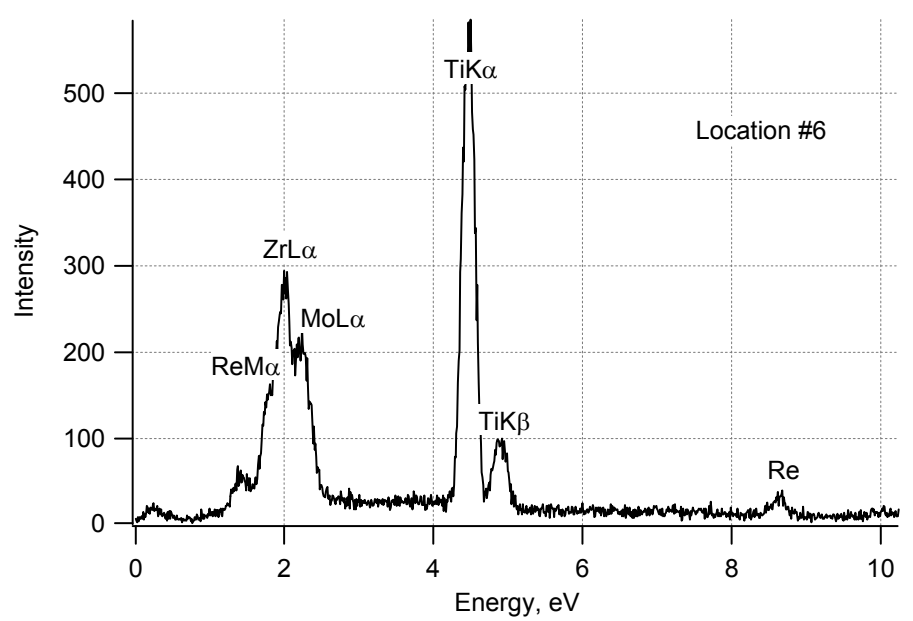

Fig. 9. EDS spectra taken in the SEM in the braze filler metal layer. The data from the phase of lighter contrast are given in (a) (Location \#5 in Fig. 7b). Data from the phase of darker contrast are given in (b) (Location \#6 in Fig. 7b.) 


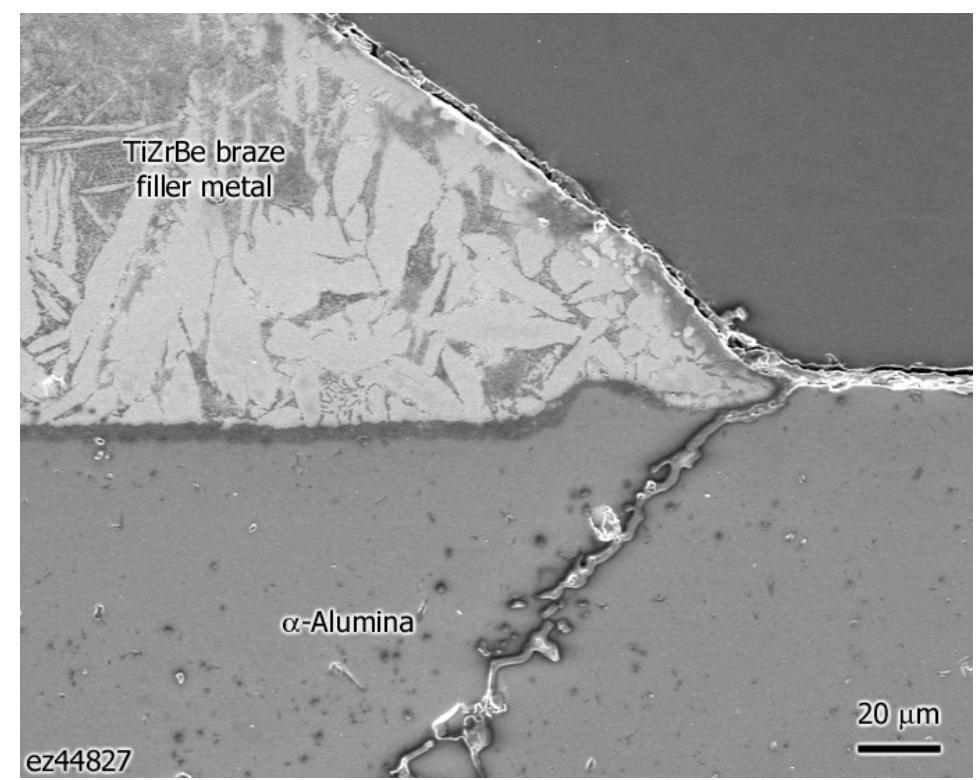

Fig. 10. SEM micrograph of microstructure near edge of braze filler metal fillet at junction with $\alpha-\mathrm{Al}_{2} \mathrm{O}_{3}$.

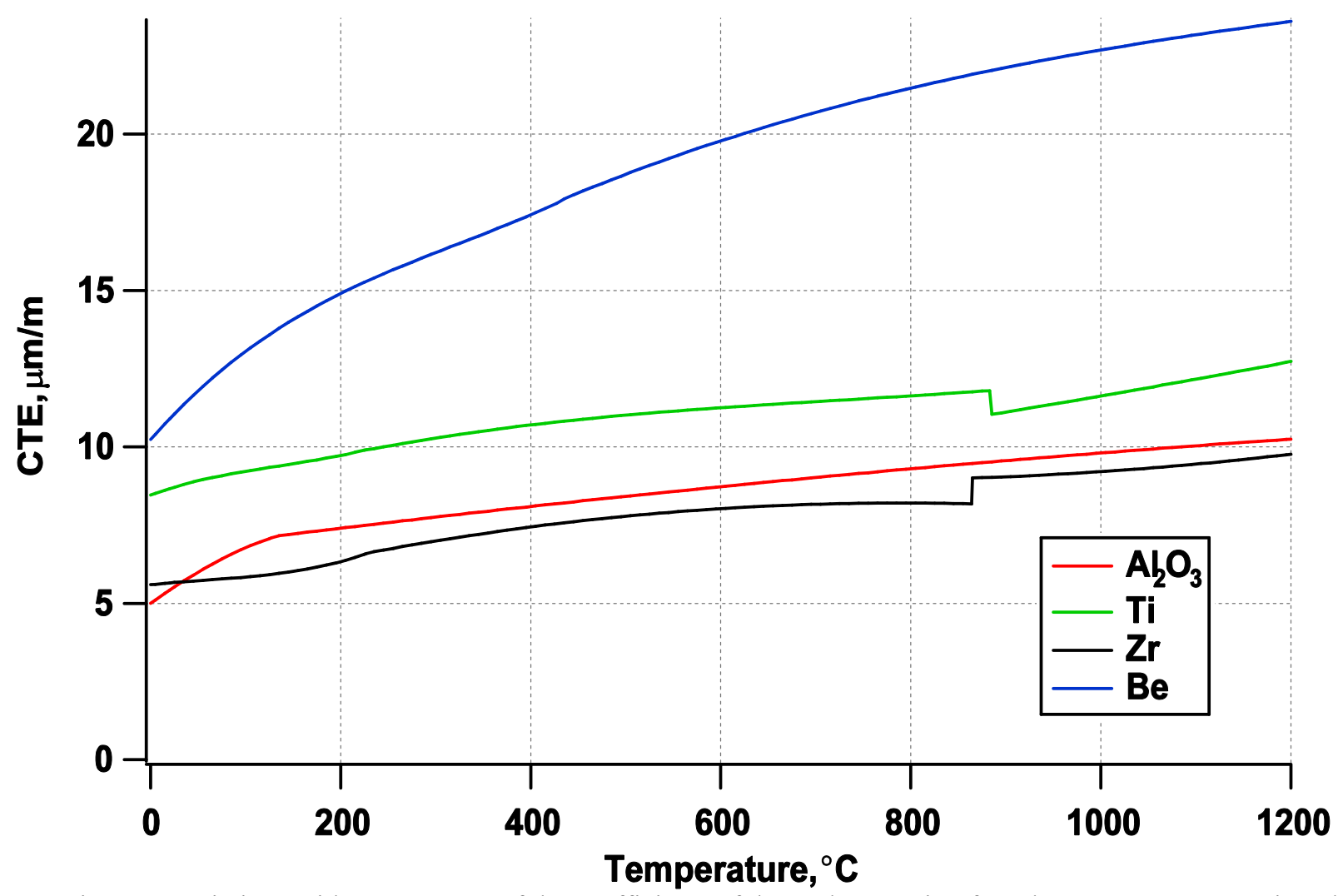

Fig. 11. Variations with temperature of the coefficients of thermal expansion for $\mathrm{Al}_{2} \mathrm{O}_{3}$, pure $\mathrm{Be}$, pure $\mathrm{Ti}$, and pure $\mathrm{Zr}$. 


\subsection{ALLOY DEVELOPMENT AND CHARACTERIZATION}

\subsubsection{Effects of Aging Up to 16 Months at $500-700^{\circ} \mathrm{C}$ on the Impact Ductility of Mo-41\%Re}

Alkali Metal Thermal-to-Electric Conversion (AMTEC) systems have the potential of producing electric power with higher conversion efficiency than the thermoelectric systems traditionally employed on board NASA deep space satellites. The primary construction material being considered for the AMTEC cell is arc-melted Mo- $41 \% \operatorname{Re}$ (all compositions in wt.\% unless noted otherwise) [1]. This alloy was chosen because of its good ductility, strength, weldability, and compatibility with liquid and vapor sodium [2]. Also, its Re concentration is low enough to minimize, if not avoid altogether, the formation of the brittle $\sigma$ phase [3]. The solubility of Re in Mo is $\sim 39.5 \%$ at $750^{\circ} \mathrm{C}$, which increases (decreases) at higher (lower) temperatures. When the solubility limit is exceeded, two Re-rich second phases can precipitate out, namely the $\sigma$ and $\chi$ phases at temperatures above and below $\sim 1125^{\circ} \mathrm{C}$, respectively.

During its service life of up to 15 years, the AMTEC cell is expected to experience operating temperatures of 350 to $900^{\circ} \mathrm{C}$ [1]. The $\sigma$ phase is stable only above $\sim 1125^{\circ} \mathrm{C}$, where nearly $44 \%$ Re is soluble in Mo; so it is unlikely that any $\sigma$ will precipitate out during service. However, the situation with the $P$ phase is somewhat different. At the upper end of the operating temperature range $\left(850-900^{\circ} \mathrm{C}\right)$, the phase diagram [3] predicts that virtually all the Re in the Mo$41 \%$ Re alloy will be in solution. At lower temperatures, however, some of the Re will come out of solution and form the $\chi$ phase since more of the $\chi$ phase is in thermodynamic equilibrium with the $\mathrm{Mo}(\mathrm{Re})$ solid solution at lower temperatures[3]. How much precipitation occurs will depend on the kinetics of $\chi$-phase formation, which are expected to be extremely slow at low temperatures but for which no detailed data exist. Therefore, it was considered prudent to evaluate the kinetics of $\chi$-phase formation in Mo- $41 \%$ Re and determine what effect, if any, aging at intermediate temperatures has on its mechanical properties. This report summarizes our preliminary results on the effects of aging (for times up to 16 months) on impact ductility. The effects of aging on mechanical properties at conventional strain rates will be discussed in future reports.

Sheet material made from the MR-1 ingot, nominal composition Mo- $41 \% \mathrm{Re}$, was received in the fully recrystallized condition (recrystallization temperature, $1200^{\circ} \mathrm{C}$ ) with a grain size of approximately $40 \mu \mathrm{m}$. Details of the various processing steps needed to produce sheet from starting powder materials are given elsewhere[1,2,4]. Tensile impact specimens were machined from the as-received sheet, placed in evacuated and sealed quartz capsules, and annealed at temperatures of 500,600 , and $700^{\circ} \mathrm{C}$ for times of 811,1505 , and $2880 \mathrm{~h}$ and at 500 and $700^{\circ} \mathrm{C}$ for $11,500 \mathrm{~h}$. Grain growth is not expected at these annealing temperatures since they are much lower than the recrystallization temperature. Tensile impact tests were performed on the annealed specimens at temperatures of 500,600 , and $700^{\circ} \mathrm{C}$ and a bullet velocity of $61 \mathrm{~m} / \mathrm{s}$ (which corresponds to a tensile strain rate of $\sim 10^{3} \mathrm{~s}^{-1}$ within the specimen gage sections), as described elsewhere [5]. Elongations to fracture were obtained by measuring the average change in spacing between several microhardness impressions placed along each specimen gage length.

Figure 1 compares the as-received microstructure of the Mo- $41 \%$ Re alloy with its microstructure after annealing for 4 months at $700^{\circ} \mathrm{C}$. There was no change in grain size after this anneal or after any of the other anneals performed in this study, including the longest anneal of 16 months $(\sim 11,500 \mathrm{~h})$. Within the resolution limits of light microscopy, no second phase particles were found in any of the aged specimens. (Transmission electron microscopy is planned in the next fiscal year to check for particles at higher magnifications.) 

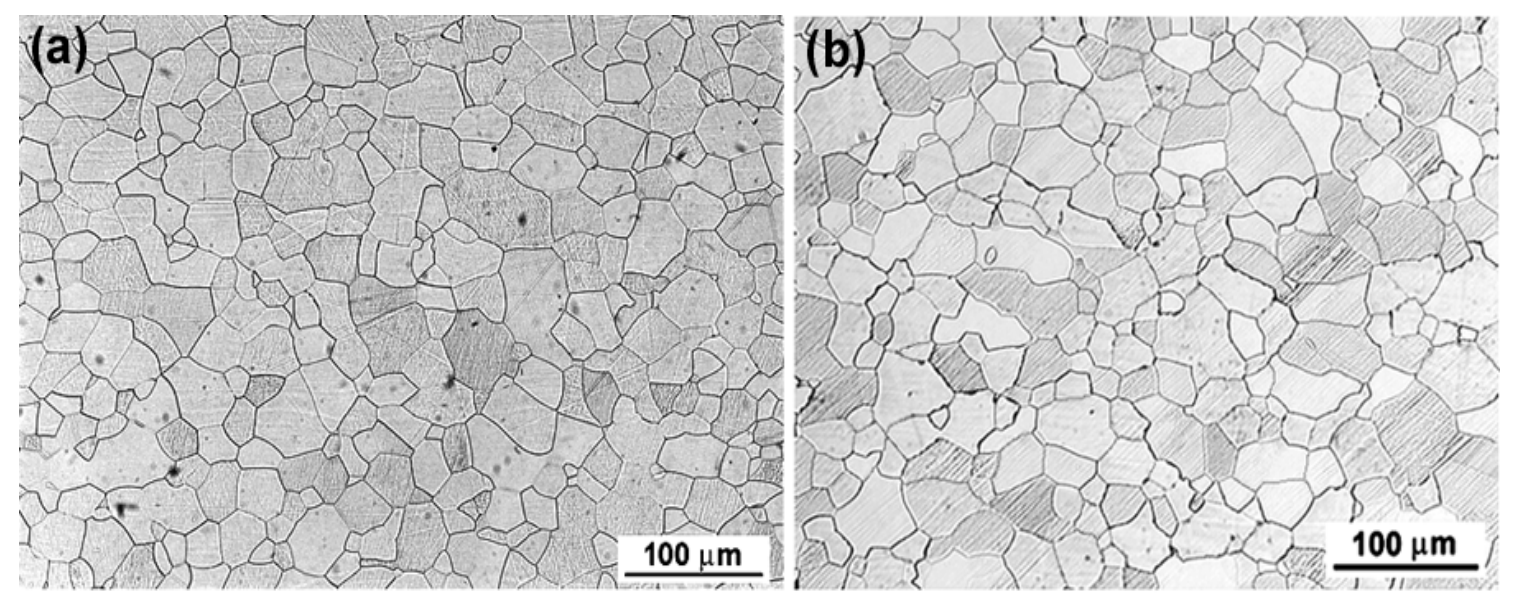

Fig. 1. Optical micrographs of Mo-41\%Re (a) as received and (b) after 4 months ( $2880 \mathrm{~h})$ at $700 \mathrm{EC}$.

Figure 2 shows the impact ductility as a function of aging time and temperature. The tensile impact tests were performed at the aging temperatures (i.e., if the aging was done at $500^{\circ} \mathrm{C}$, the impact tests were performed at $500^{\circ} \mathrm{C}$, and so on). Duplicate specimens were tested for each experimental condition. Ductility remains high and roughly the same for all aging times and temperatures. These results suggest that either $\chi$-phase precipitation was not significant under these aging conditions, or the $\chi$-phase precipitates do not compromise elevated-temperature impact ductility. Additional tests are planned for the next fiscal year to distinguish between these two possibilities.

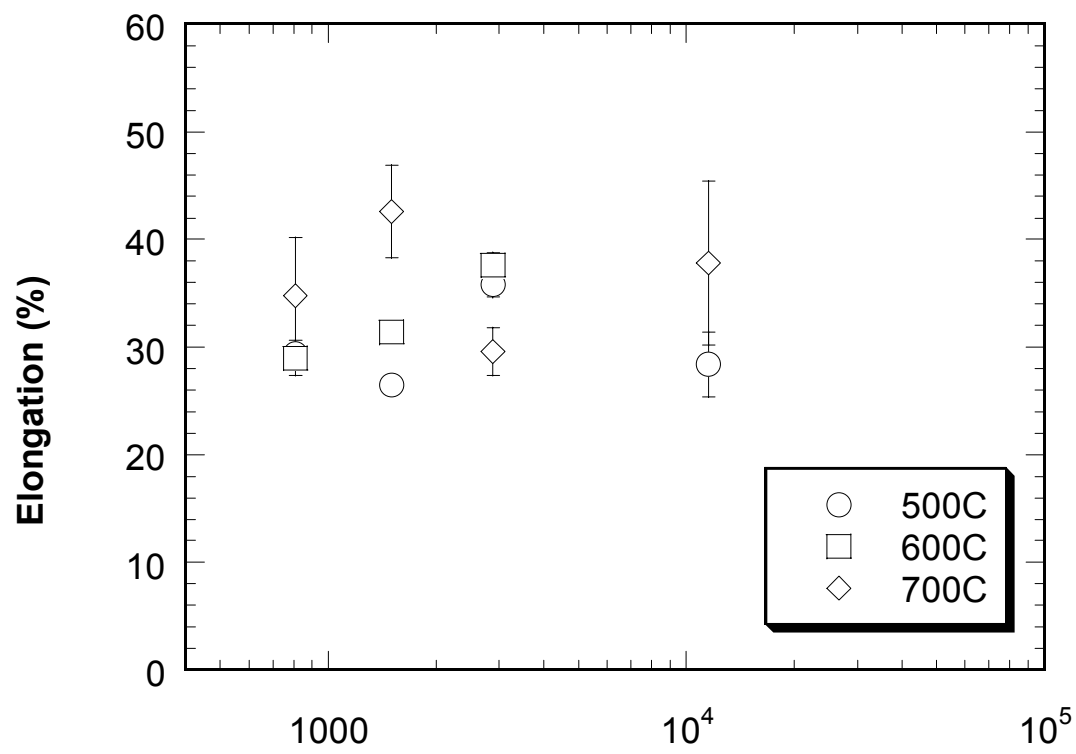

Aging Time (h)

Fig. 2. Effect of aging time and temperature on impact ductility of Mo- $41 \%$ Re. Bullet velocity $\sim 61 \mathrm{~m} / \mathrm{s}$ which corresponds to tensile strain rate of $\sim 10^{3} \mathrm{~s}^{-1}$ in gage section.

Consistent with the high ductilities measured in the tensile impact tests, fracture occurred in an extremely ductile manner with the specimens necking to a knife edge. Figure 3 shows representative fractographs of a specimen impact tested at $500^{\circ} \mathrm{C}$ after a $500^{\circ} \mathrm{C}$ anneal for $1505 \mathrm{~h}$. The other specimens exhibited similar fracture modes. 

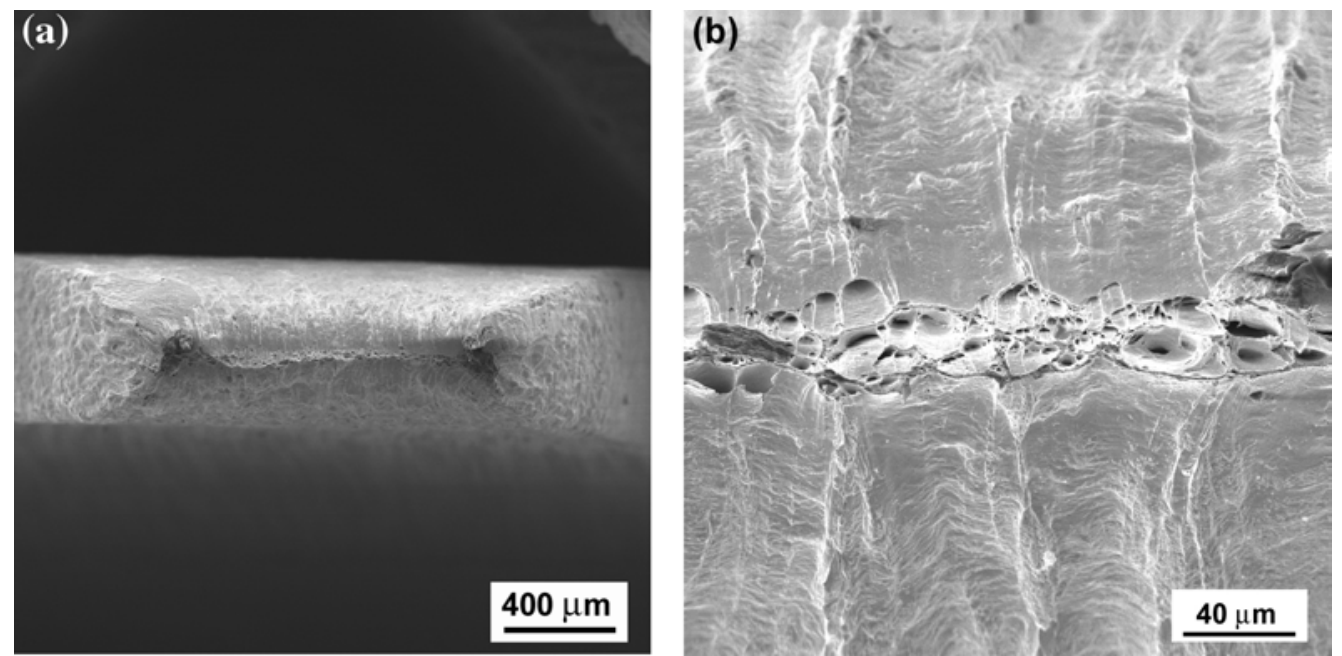

Fig. 3. Scanning electron fractographs of impact fractures in Mo-41\%Re after aging for (a) $1505 \mathrm{~h}$ at $500 \mathrm{EC}$ and (b) $11,500 \mathrm{~h}$ at $700 \mathrm{EC}$.

In summary, Mo- $41 \%$ Re specimens were aged in vacuum at temperatures of $500-700^{\circ} \mathrm{C}$ for times up to 16 months $(\sim 11,500 \mathrm{~h})$ and then tensile impact tested at the aging temperatures to determine whether these intermediate temperature anneals had any deleterious effects on ductility. Our preliminary results indicate that they did not. Additional experiments are planned during the next fiscal year to extend these investigations to conventional strain rates and to quantify the kinetics of $\chi$-phase precipitation in Mo- $41 \%$ Re alloys.

\section{References}

1. J. P. Moore, J. F. King, J. R. DiStefano, and E. K. Ohriner, in Proc. Space Technology and Applications International Forum (STAIF-2002), February 3-7, 2002, Albuquerque, NM, paper log\# 202/D10.

2. J. F. King, J. R. DiStefano, J. P. Moore, and E. K. Ohriner, "Production and properties of Mo-41\%Re for AMTEC cell construction," attachment to Letter No. 0929-46-00, J. P. Moore to A. S. Mehner and L. C. Herrera, September 29, 2000.

3. Binary Alloy Phase Diagrams (editor-in-chief T. B. Massalski), American Society for Metals, Metals Park, Ohio (1986).

4. Semiannual Technical Progress Report of the Radioisotope Power System Materials Production and Technology Program Tasks for September 2000 through March 2001, ORNL/CF-01/24, May 8, 2001.

5. C. T. Liu, H. Inouye, and A. C. Schaffhauser, Metall. Trans. A12 (1981) 993. 


\subsection{PLUTONIUM PRODUCTION STUDIES}

\subsection{Target Development}

Fourteen neptunium target capsules were irradiated in the Advanced Test Reactor (ATR) at Idaho National Engineering and Environmental Laboratory (INEEL) for the purpose of providing data to support the ${ }^{238} \mathrm{Pu}$ production program. These capsules were shipped to the Irradiated Fuels Examination Laboratory (IFEL) at Oak Ridge National Laboratory (ORNL) for removal from their irradiation basket, visual examination, analysis of ${ }^{85} \mathrm{Kr}$ content, and gas pressure measurements.

\subsubsection{Test Description}

Two fuel types that differ in their ${ }^{237} \mathrm{~Np}$ content are represented in this post-irradiation examination (PIE). Seven targets contain $10 \%$ pellets and seven targets contain $20 \%$ pellets. The pellets are a dispersion fuel composed of ${ }^{237} \mathrm{~Np}$ oxide powder and powdered aluminum pressed into a pellet die.

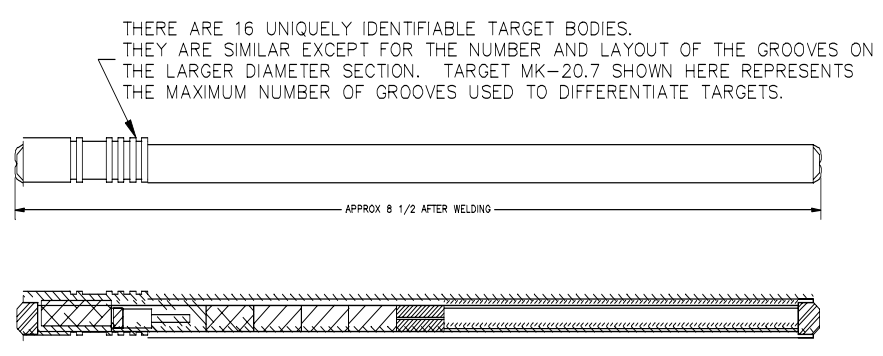

Fig. 1. Capsule geometry and internal construction.

The pellets and spacing hardware were loaded into aluminum capsules and sealed by welding in an inert (helium) atmosphere. The capsules were then loaded into a basket assembly that was subsequently inserted into the ATR for irradiation in a large B position. After irradiation, the basket assembly was cut into segments for transportation. Figure 1 shows the capsule geometry and Fig. 2 shows one section of the segmented basket assembly. Figure 3 shows the targets. Two assemblies, each containing seven targets were shipped to ORNL. 
The capsule pressure was measured by drilling into the capsule top, capturing the released gasses in a calibrated volume, and measuring their pressure. The known capsule internal volume, the apparatus volume, and the ideal gas law was used to determine the capsule pressure. The captured gasses were routed through a trap system to capture and measure their ${ }^{85} \mathrm{Kr}$ inventory. Together, the pressure and radioactive krypton (the only source is the fuel pin inventory) provide a sensitive measure of the fuel gas release data. Figure 4 illustrates the apparatus used to obtain gas samples.
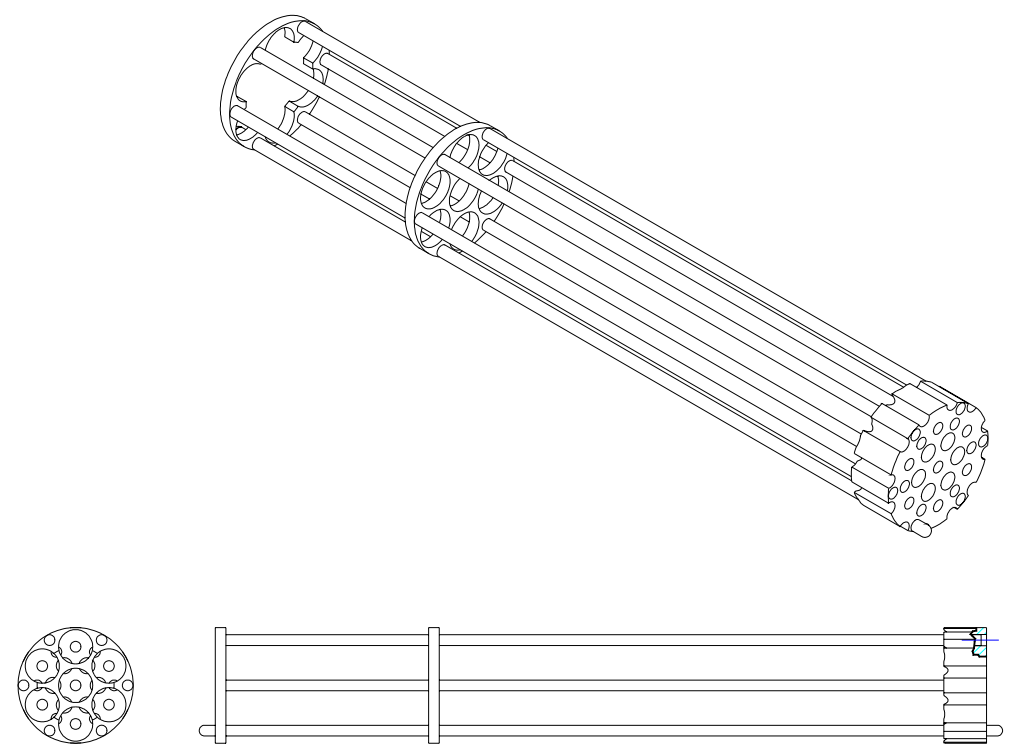

Fig. 2. One section of the segmented basket assembly. Seven capsules are contained per basket during irradiation.

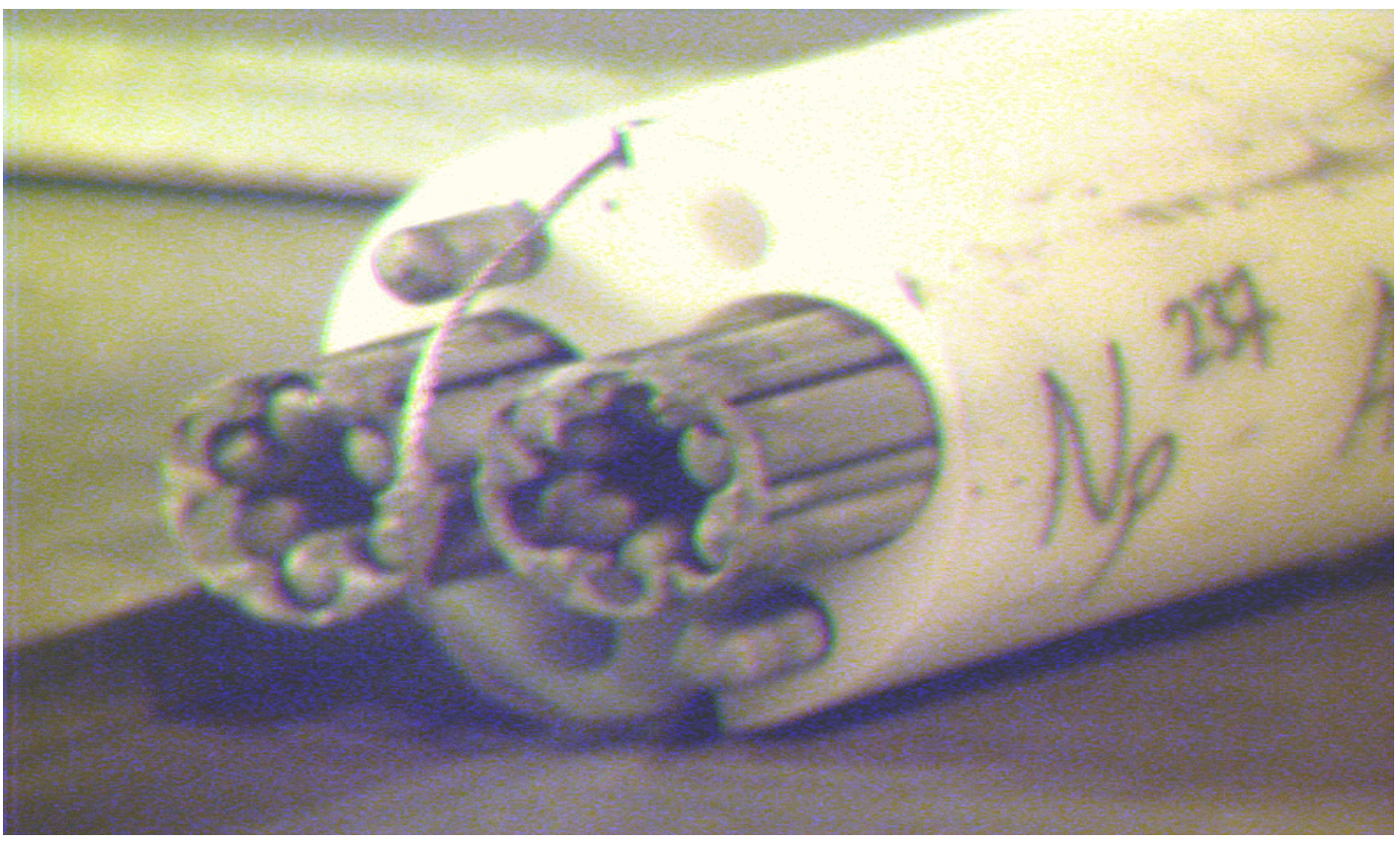

Fig. 3. Irradiated targets prior to examination. 


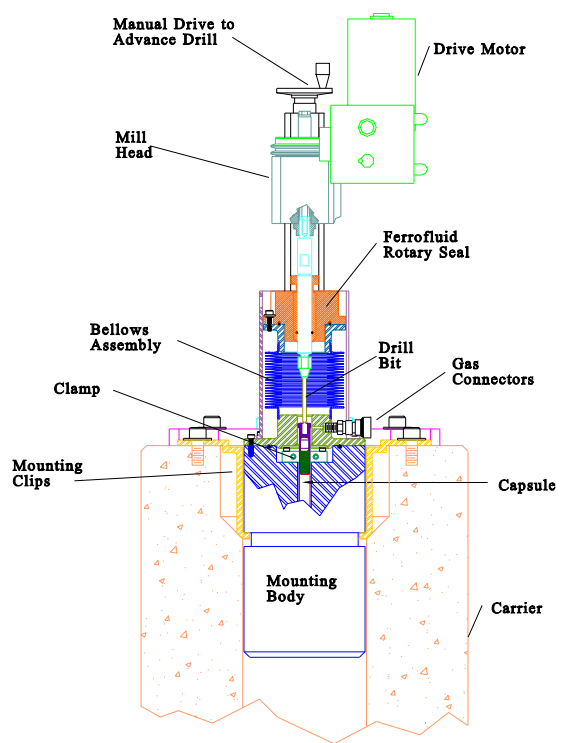

Fig. 4. Schematic of the gas measurement apparatus.

\subsubsection{Results}

Table 1 shows data collected for several targets. The targets selected for analysis represented extremes in power levels in the reactor. For the targets containing pellets at $20 \mathrm{vol} \% \mathrm{NpO}_{2}$, target $\mathrm{Np}-10$ saw a relative power level of 1.72 while target $\mathrm{Np}-13$ saw a relative power of 0.46 . Both targets showed ${ }^{85} \mathrm{Kr}$ release fractions near $6 \%$. For targets containing pellets at $10 \mathrm{vol} \% \mathrm{NpO}_{2}$, target $\mathrm{Np}-2$ saw a relative power level of 1.7 while target $\mathrm{Np}-5$ showed a relative power level of 0.49. Examination of the ${ }^{85} \mathrm{Kr}$ release fraction for $\mathrm{Np}-2$ indicates about $5.28 \%$ of the available ${ }^{85} \mathrm{Kr}$ was released whereas, the lower exposure Np-5 targets showed a $3.0 \%$ release of available ${ }^{85} \mathrm{Kr}$. The fractional release of ${ }^{85} \mathrm{Kr}$ was between 0.5 to $6 \%$ of the predicted ${ }^{85} \mathrm{Kr}$ inventory. The balance of the ${ }^{85} \mathrm{Kr}$ is retained in the $\mathrm{NpO}_{2}$ oxide matrix as is the case with similar curium targets.

There were some unexpected results during these tests. When the target body $\mathrm{Np}-10$ was penetrated, the gas pressure sensors showed a rapid rise in pressure which damaged the sensor, causing it to fail. On another occasion, target Np-11 exhibited similar behavior except that the spike did not cause permanent damage to the sensor and a final pressure of $357 \mathrm{psig}$ was determined as the existing pressure in the target. Both of these targets exhibited highly unusual behavior as compared to the other targets which yielded sub-atmospheric pressure.

The release data in Table 1 will allow us to develop better estimates of fission gas release in the targets. Unfortunately, since two of the targets yielded relatively high pressures, additional examination will be necessary to determine possible mechanisms for the high pressures. 
Table 1. Summary of post-irradiation gas sampling for array targets

\begin{tabular}{|c|c|c|c|c|c|c|c|c|c|}
\hline $\begin{array}{l}\text { Target } \\
\text { number }\end{array}$ & $\begin{array}{l}\text { Target } \\
\text { body }\end{array}$ & $\begin{array}{c}\text { Location in } \\
\text { reactor }\end{array}$ & $\begin{array}{c}\text { Relative } \\
\text { power }\end{array}$ & $\begin{array}{c}\text { Pressure } \\
\text { measurement } \\
\text { (psia) }\end{array}$ & $\begin{array}{l}\text { Experimental } \\
\mathrm{Kr}-85 \\
\text { inventory }(\mathrm{Ci})\end{array}$ & $\begin{array}{c}\text { Predicted gas } \\
\text { content } \\
\text { (moles) }\end{array}$ & $\begin{array}{l}\text { Predicted } \\
\text { pressure } \\
\text { increase } \\
\text { (psia) }\end{array}$ & $\begin{array}{l}\text { Predicted } \mathrm{Kr}- \\
85 \text { inventory } \\
\quad(\mathrm{uCi})\end{array}$ & $\begin{array}{c}\text { Fractional release } \\
\text { of fission gases } \\
\text { based on Kr-85 } \\
(\%)\end{array}$ \\
\hline $\mathrm{Np}-12$ & 20.3 & 1 & 0.65 & & & $4.8080 \mathrm{E}-05$ & 9.49 & $5.0490 \mathrm{E}-03$ & \\
\hline $\mathrm{Np}-13$ & 20.4 & 2 & 0.46 & 5.4 & $2.06 \mathrm{E}-04$ & $3.2680 \mathrm{E}-05$ & 6.45 & $3.7540 \mathrm{E}-03$ & 5.49 \\
\hline $\mathrm{Np}-14$ & 20.5 & 3 & 0.72 & 10 & $2.69 \mathrm{E}-05$ & $5.0950 \mathrm{E}-05$ & 10.06 & 5.3910E-03 & 0.50 \\
\hline $\mathrm{Np}-09$ & 20.0 & 4 & 1.38 & & & $8.9650 \mathrm{E}-05$ & 17.70 & $9.7800 \mathrm{E}-03$ & \\
\hline $\mathrm{Np}-10$ & 20.1 & 5 & 1.72 & $* *$ & 7.39E-04 & $1.0830 \mathrm{E}-04$ & 21.39 & $1.1900 \mathrm{E}-02$ & 6.21 \\
\hline $\mathrm{Np}-11$ & 20.2 & 6 & 1.25 & 357 & $4.03 \mathrm{E}-04$ & $8.0840 \mathrm{E}-05$ & 15.96 & $8.7710 \mathrm{E}-03$ & 4.59 \\
\hline $\mathrm{Np}-15$ & 20.6 & 7 & 0.81 & 8.1 & $3.40 \mathrm{E}-04$ & $5.5420 \mathrm{E}-05$ & 10.94 & $5.8670 \mathrm{E}-03$ & 5.80 \\
\hline $\mathrm{Np}-4$ & 10.3 & 1 & 0.67 & & & $2.2770 \mathrm{E}-05$ & 4.50 & $2.3730 \mathrm{E}-03$ & \\
\hline $\mathrm{Np}-5$ & 10.4 & 2 & 0.49 & 8.8 & $5.94 \mathrm{E}-05$ & $1.9140 \mathrm{E}-05$ & 3.78 & $1.9790 \mathrm{E}-03$ & 3.00 \\
\hline Np-6 & 10.5 & 3 & 0.66 & & & $2.4870 \mathrm{E}-05$ & 4.91 & $2.6120 \mathrm{E}-03$ & \\
\hline Np-1 & 10.0 & 4 & 1.25 & & & $4.1260 \mathrm{E}-05$ & 8.15 & $4.4690 \mathrm{E}-03$ & \\
\hline $\mathrm{Np}-2$ & 10.1 & 5 & 1.7 & 6.2 & $3.10 \mathrm{E}-04$ & $5.2760 \mathrm{E}-05$ & 10.42 & $5.8730 \mathrm{E}-03$ & 5.28 \\
\hline $\mathrm{Np}-3$ & 10.2 & 6 & 1.32 & 7.6 & $1.73 \mathrm{E}-04$ & $4.0960 \mathrm{E}-05$ & 8.09 & $4.4410 \mathrm{E}-03$ & 3.90 \\
\hline $\mathrm{Np}-7$ & 10.6 & 7 & 0.91 & 4.1 & $1.32 \mathrm{E}-04$ & $3.1390 \mathrm{E}-05$ & 6.20 & $3.3430 \mathrm{E}-03$ & 3.95 \\
\hline
\end{tabular}




\subsubsection{Target Design Planning}

Based on limited results from dosimeter targets, pellet targets, and array targets, the thermal hydraulic behavior in the reflector positions appears to remain an issue with regard to target design. Although the ${ }^{236} \mathrm{Pu}$ content was a significant concern identified in early computational studies, the relatively low ${ }^{236} \mathrm{Pu}$ content observed in both the dosimeter and pellet targets indicate that the more favorable lower cross-section sets are likely to be better predictors of ${ }^{236} \mathrm{Pu}$ content. The next area of concern becomes thermal hydraulic behavior in the reflector positions since computational analysis pointed to relatively high fission rates at the end of irradiation. These targets are generating more heat at the end of the cycle than at the beginning which, in turn, places significant limits on either the total material loaded or the total exposure time. Currently, a thermal flux value limit of $\sim 10^{6} \mathrm{BTU} / \mathrm{hr}\left(\mathrm{b}^{2}\right.$ is anticipated for these targets based on work in the High Flux Isotope Reactor (HFIR). As such, a slightly smaller target will yield a higher surface area to volume ratio and would be expected to run cooler for a given neptunium loading.

For this design, we will use the targets with properties as follows:

Pellet diameter 0.19"

Clad thickness 0.03"

Target outer diameter $0.25 "$

Gap between clad and pellet $0.001 "$

Fill gas-helium

Pellet Density— $90 \%$ of theoretical density

The amount of $\mathrm{NpO}_{2}$ in the target will be modeled at two different levels of $\mathrm{NpO}_{2}$ in the pellets in the target in order to examine the effect of $\mathrm{NpO}_{2}$ content on ${ }^{238} \mathrm{Pu}$ production, ${ }^{236} \mathrm{Pu}$ impurity and thermal analysis. The two values to be used, expressed as the volume fraction of $\mathrm{NpO}_{2}$ in the pellet are 0.10 volume fraction and 0.20 volume fraction. If the results from the basic analysis are favorable with respect to thermal performance, we may wish to increase neptunium loading by increasing the diameter of the target or increasing the volume fraction of $\mathrm{NpO}_{2}$.

The preliminary results of the array target PIE indicate that the void volume available at $90 \%$ of theoretical density should provide sufficient free volume to maintain operating pressure below 200 psia at $900 \mathrm{EF}$. A final safety review will be required to confirm this assumption; however, no internal plenum will be included in the model.

\subsection{TECHNOLOGY DEVELOPMENT}

Technology development efforts focused efforts on studies to support neptunium transfer from Savannah River Site (SRS) to Oak Ridge. These studies took form in an experimental study to determine whether or not hydrogen is generated during long-term storage while the second study examined long-term storage options in Oak Ridge. These studies are summarized in the following subsections.

\subsubsection{Baseline Plan for Neptunium Stabilization}

The processing scheme to convert the neptunium from a liquid solution to a solid oxide for long-term storage is shown in Fig. 5. The processing will involve transfer of the neptunium containing solution to the glove-box line in HB-Line Phase II, anion exchange to remove selected chemical impurities followed by oxalate conversion. The oxalate product will then be calcined to produce oxide and transferred into containers, eventually being placed into a $9975 \mathrm{drum}$. The drum intended to be used for $\mathrm{NpO}_{2}$ storage for $\sim 30$ years. Recent studies concerning long-term storage of uranium and 


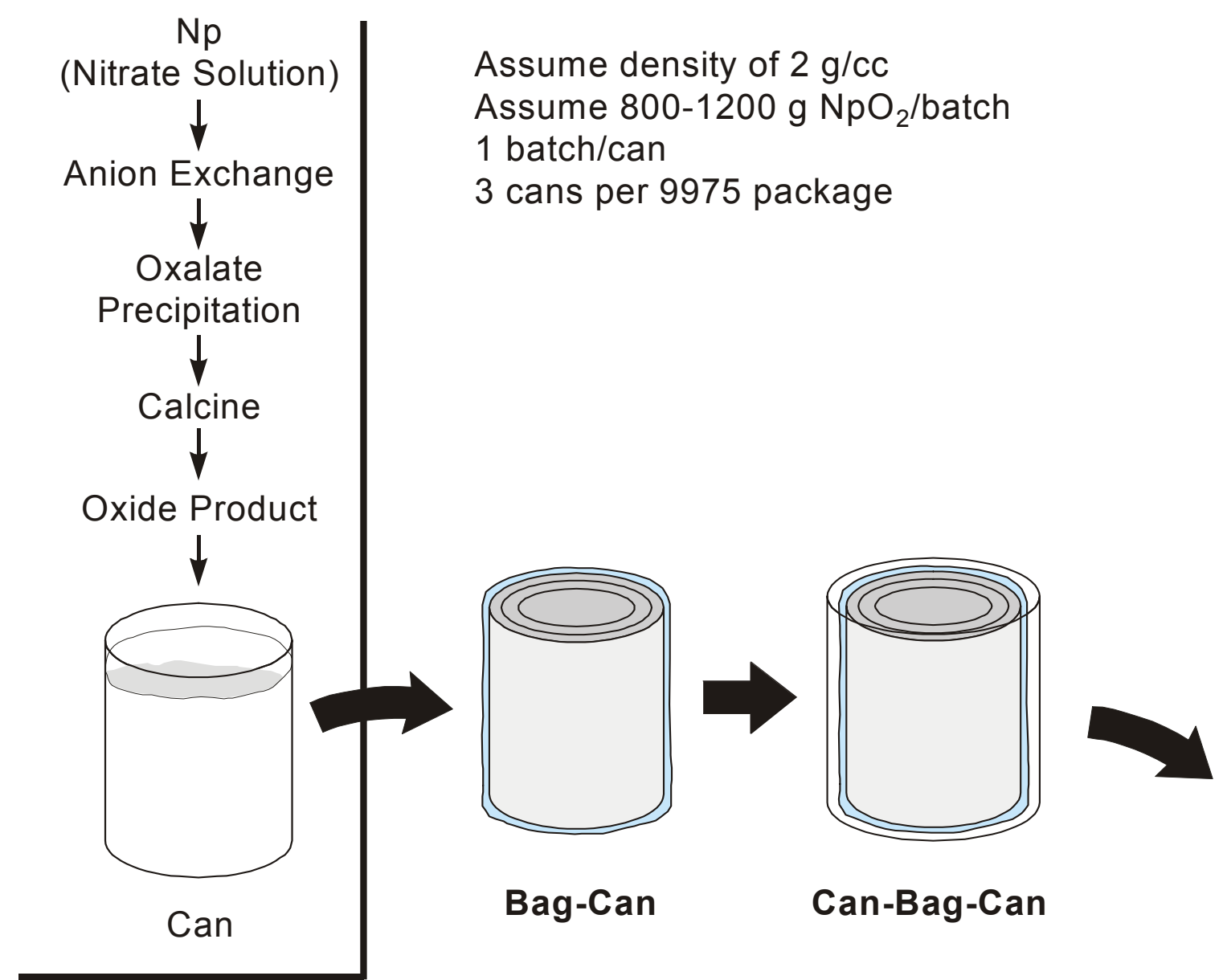

Confinement Barrier

Fig. 5. Processing plan of neptunium stabilization at Savannah River.

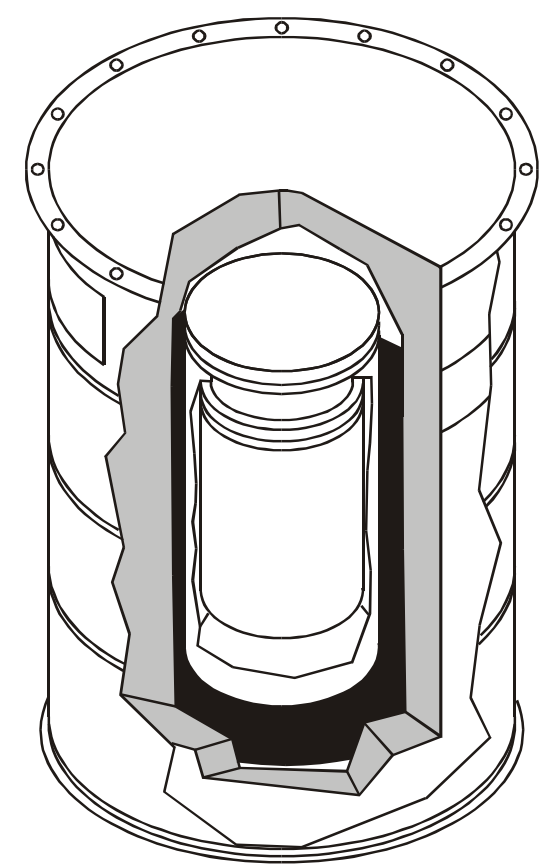

9975 Package (35 gal) 
plutonium oxides at ORNL, SRS, and LANL have shown a potential for hydrogen generation depending on material condition, water content, and irradiation conditions (e.g., whether materials were irradiated with external gamma sources or alpha emitters included in the sample matrix). An experimental study was developed and carried out to assess the potential for hydrogen generation.

\subsubsection{Experimental Sample Preparation}

The experimental program was divided into three distinct activities: sample preparation, water sorption studies and radiolysis experiments.

Twelve samples of $\mathrm{NpO}_{2}$ were prepared and then irradiated to evaluate radiolytic decomposition of water. The samples first underwent chemical processing to prepare the $\mathrm{NpO}_{2}$ in a form similar to that expected from SRS. The two variables examined which effect gas generation-water content of the material and the specific surface area per unit weight - where varied to look at the effects on hydrogen production. The water content is important since water is radiolyzed to hydrogen and oxygen, thus influencing the total hydrogen production. The specific surface area, in $\mathrm{m}^{2} / \mathrm{gm}$, determines how much water can be absorbed on the surface. Both of these effects were studied in these experiments.

In order to prepare $\mathrm{NpO}_{2}$ for these experiments, a batch of $80-100 \mathrm{~g}$ of $\mathrm{NpO}_{2}$ was dissolved in nitric acid. The dissolution process took several individual steps due to difficulties in dissolving the $\mathrm{NpO}_{2}$. The starting $\mathrm{NpO}_{2}$ had been high fired ( 1300EC) and was extremely difficult to dissolve. After dissolution, the valence of neptunium was adjusted to the +4 valence state by addition of hydrazine followed by ascorbic acid. A slight excess of oxalic acid was then

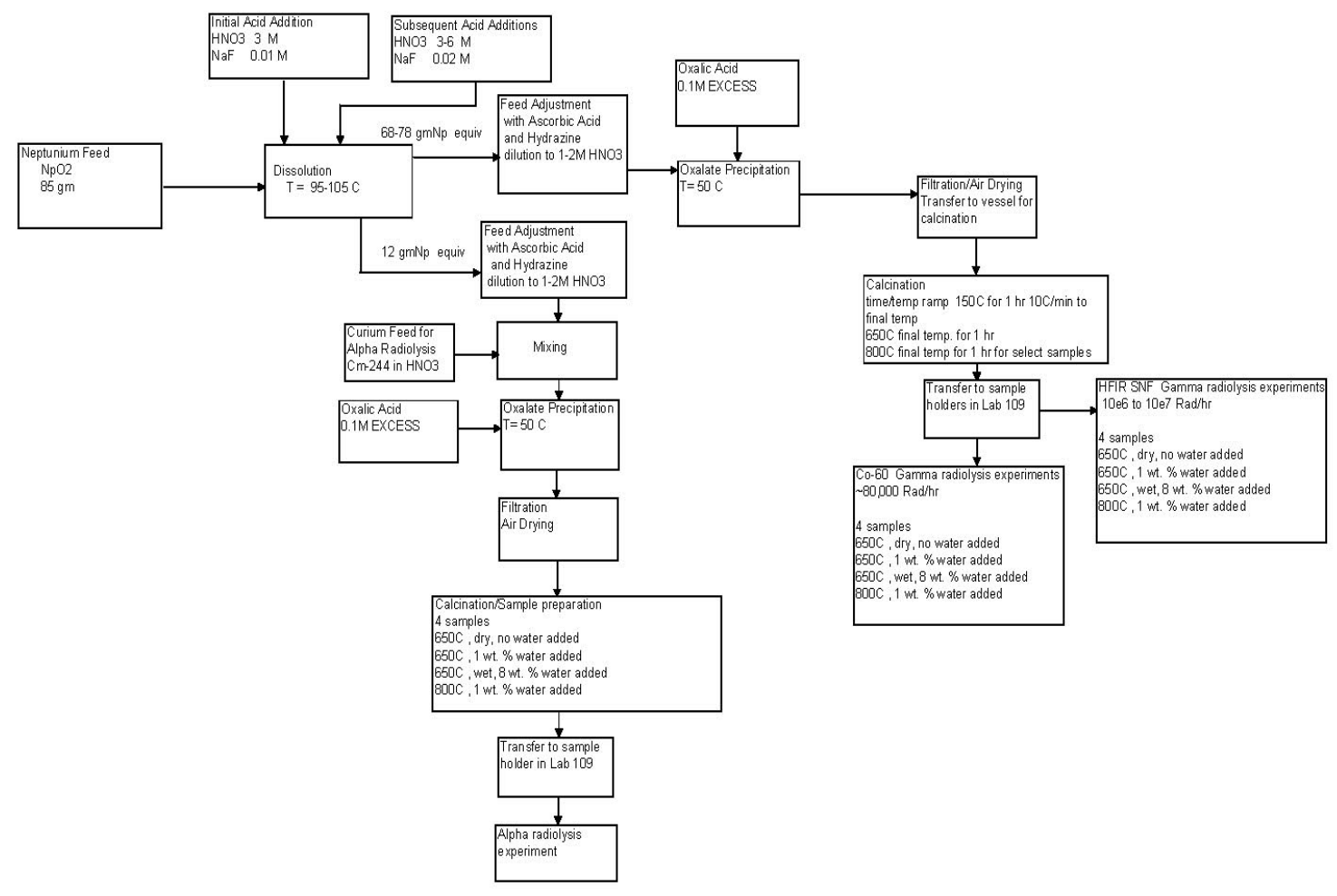

Fig. 6. Flowsheet for preparing neptunium oxalate. 
added to precipitate the neptunium as neptunium oxalate. The resulting material was filtered, dried, and fired to $650 \mathrm{EC}$ to convert the oxalate to oxide. Figure 6 shows the various steps required to prepare the various samples. The second temperature of $800 \mathrm{EC}$ was chosen to give a change in surface area. Similar oxalate products made with plutonium showed a decrease in surface area from $\sim 14 \mathrm{~m}^{2} / \mathrm{gm}$ for material fired at $650 \mathrm{EC}$ to $\sim 6 \mathrm{~m}^{2} / \mathrm{gm}$ for material fired at $800 \mathrm{EC}$ based on information from SRS.

Neptunium oxide with varying amounts of sorbed water was needed for these experiments. The amount of water sorbed as a function of time was determined by placing these materials in a controlled-humidity environment. The humidity was controlled by placing the $\mathrm{NpO}_{2}$ sample in a small glass container which, in turn, was placed in a glass desiccator. The desiccant had been removed and was replaced with a small open container of the dilute sulfuric acid yielding a constant relative humidity of $97.5 \%$.

Three series of irradiation experiments were performed, each using four samples for a total of twelve experiments. The first series used a Co-60 irradiator which is indicative of low gamma dose rate and relatively short time periods. The second series used a spent fuel element from the HFIR which is indicative of high gamma dose rates and long time periods. The third series used ${ }^{244} \mathrm{Cm}$ as an alpha emitter immersed in the matrix. This represented the effect of ${ }^{238} \mathrm{Pu}$ contamination of the $\mathrm{NpO}_{2}$ product. Moisture content was varied in each series. Three samples of each series were fired to $650 \mathrm{EC}$ and one sample was fired to $800 \mathrm{EC}$. The four sample types are described below.

1. Dry sample-fired at 650EC. This represents a condition where oxide is fired at the base-case temperature and transferred immediately after cooling to the oxide container. It is estimated to contain about $0.5 \mathrm{wt} \%$ or less water.

2. Normal sample - fired at 650EC. This is expected to represent about $24-48$ hours of residence time in a humid environment prior to transferring the oxide into the can. This may contain about $1 \mathrm{wt} \%$ water.

3. Saturated - fired at 650 EC. This represents $\mathrm{NpO}_{2}$ that sits in a humid environment and a maximum amount of water is sorbed onto the surface of the $\mathrm{NpO}_{2}$. This sample contained $8 \mathrm{wt} \%$ water.

4. Normal - fired at $800 \mathrm{EC}$. In this case the material will be fired to a temperature of $800 \mathrm{EC}$ prior to use. The higher temperature firing is expected to result in a lower total water uptake because of the reduction in surface area. The sample contained $1 \mathrm{wt} \%$ water.

The $\mathrm{NpO}_{2}$ sample was removed and weighted to determine the uptake of water. Figure 7 shows the fractional uptake of water over about four months. A value of $8 \mathrm{wt} \%$ water was taken as an upper found since it took about 60 days to achieve third moisture level and it represents a moisture content much greater than that envisioned for the stored $\mathrm{NpO}_{2}$.

Eleven of the twelve experiments are undergoing irradiation under conditions mentioned previously until steady state conditions are achieved. The exception was the high moisture content alpha radiolysis experiment which continued to show increasing gas pressure throughout the experiment and required an intermediate step to remove gas from the sample container. The following sections describe the results in greater detail.

\subsubsection{Co-60 Irradiation}

Figure 8 shows the change in gas pressure as a function of time for the four samples undergoing Co-60 irradiation. Two results stand out as being particularly notable. First, the gas pressure in Tubes 1,3, and 4 show rapid equilibration and reach steady state after a very short time. Pressure in Tube $1, \mathrm{NpO}_{2}$ fired at $650 \mathrm{EC}$, dry conditions, shows a slight vacuum compared to initial gas pressure. This could be indicative of oxygen consumption although gas samples will be required in order to propose a mechanism for the vacuum. Tubes $3, \mathrm{NpO}_{2}$ fired at $650 \mathrm{EC}$ with $2 \mathrm{wt} \%$ moisture, reached a steady state pressure early in the experiment as did Tube $4, \mathrm{NpO}_{2}$ fired at $800 \mathrm{EC}, 1 \%$ moisture. Tube $2 \mathrm{NpO}_{2}$ fired at $650 \mathrm{EC}, 8 \mathrm{wt} \%$ water shows an increase in pressure from a nominal 760 torr to $\sim 920$ torr representing an increase in pressure of about $3 \mathrm{psig}$. The pressure has not yet (as of 9/30/02) shown that it is at steady state so the experiment has been left to continue until a pressure plateau is approached. At the completion of the experiments the gas composition inside all of the tubes will be analyzed to determine which, if any, chemical reactions dominated during radiolysis. 


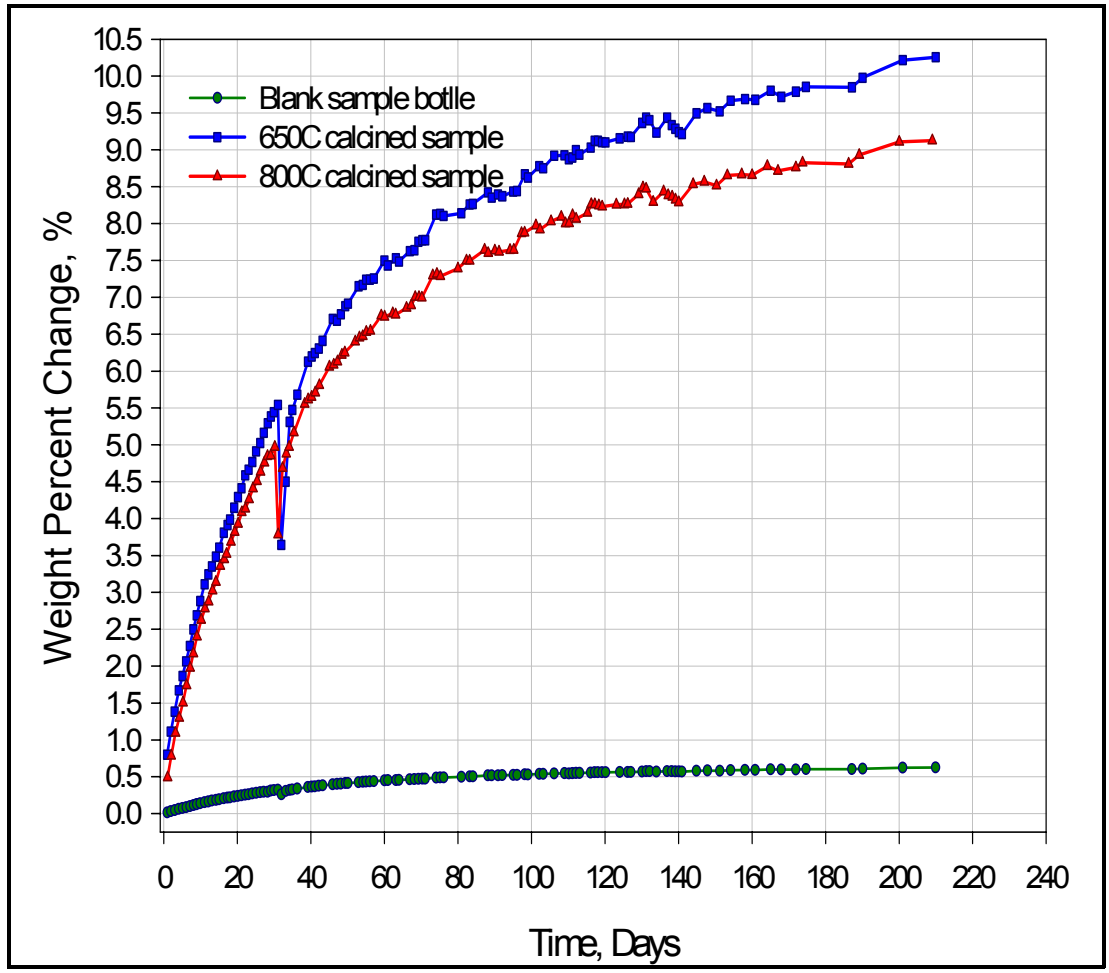

Fig. 7. Weight percentage increase in the blank sample, $650 \mathrm{EC}$, and 800 EC calcined $\mathrm{NpO}_{2}$ powders.

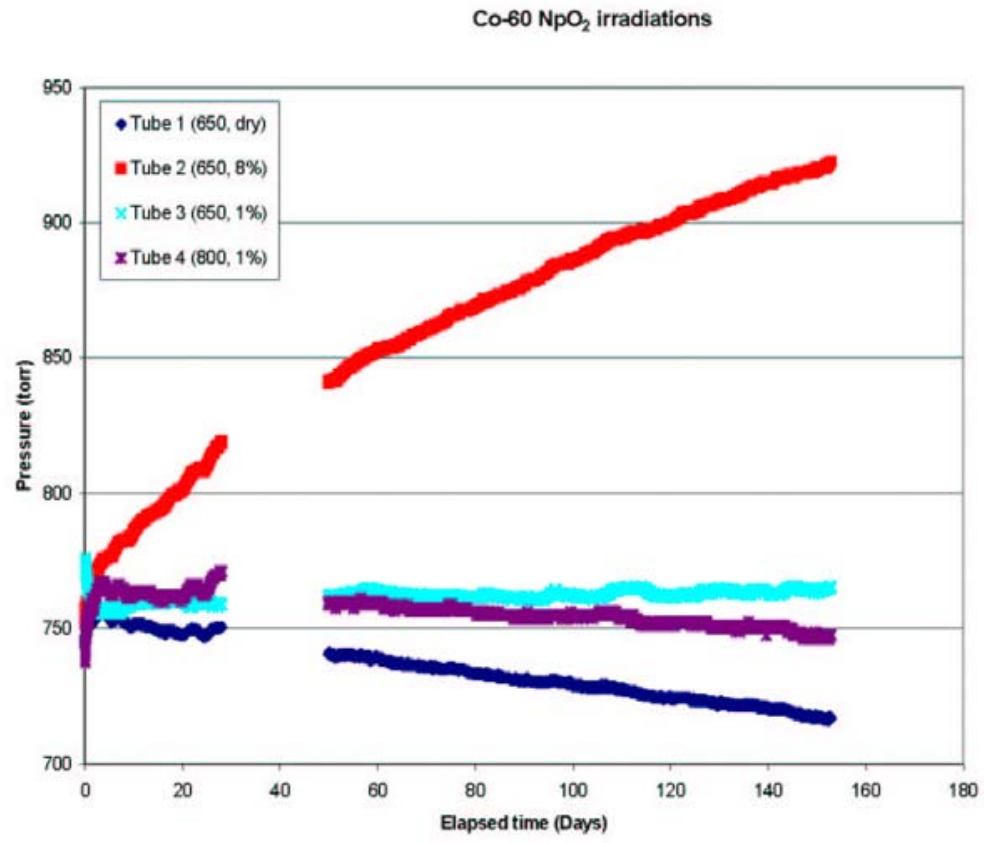

Fig. 8. Pressure as a function of elapsed time for $\mathrm{NpO}_{2}$ irradiated by ${ }^{60} \mathrm{Co}$. 


\subsubsection{HFIR SNF Irradiation}

Figure 9 shows the gas pressure in each tube as a function of time for all four tubes. The first transient, lasting only a few hours, was a pressure increase due to a sudden increase in temperature (water in the spent element is warmer than the air temperature in the reactor bay area). Gas pressures decreased in all tubes until $\sim 20$ days. At this point, the samples were removed from one spent element and placed in a fresh element. Again, the pressures increased due to temperature of the element. At about 35 days, the pressure inside the sample denoted as $\mathrm{P}-3,650 \mathrm{EC}, 8 \mathrm{wt} \%$ water, showed an apparent decrease followed by an increase which began to level out at about day 42 . The cause of this transient is still under investigation. All four samples appeared to level out from day 50 to about day 78. On or about day 78 , the gas pressure in the outer vessel dropped to a point near the lower level alarm so the experiment was moved from the spent fuel element (Note: The outer vessel did not contain any sample material). The experiment was evaluated for a potential leak and it was determined that there was not a leak. The experiment was then reinserted in the spent care.

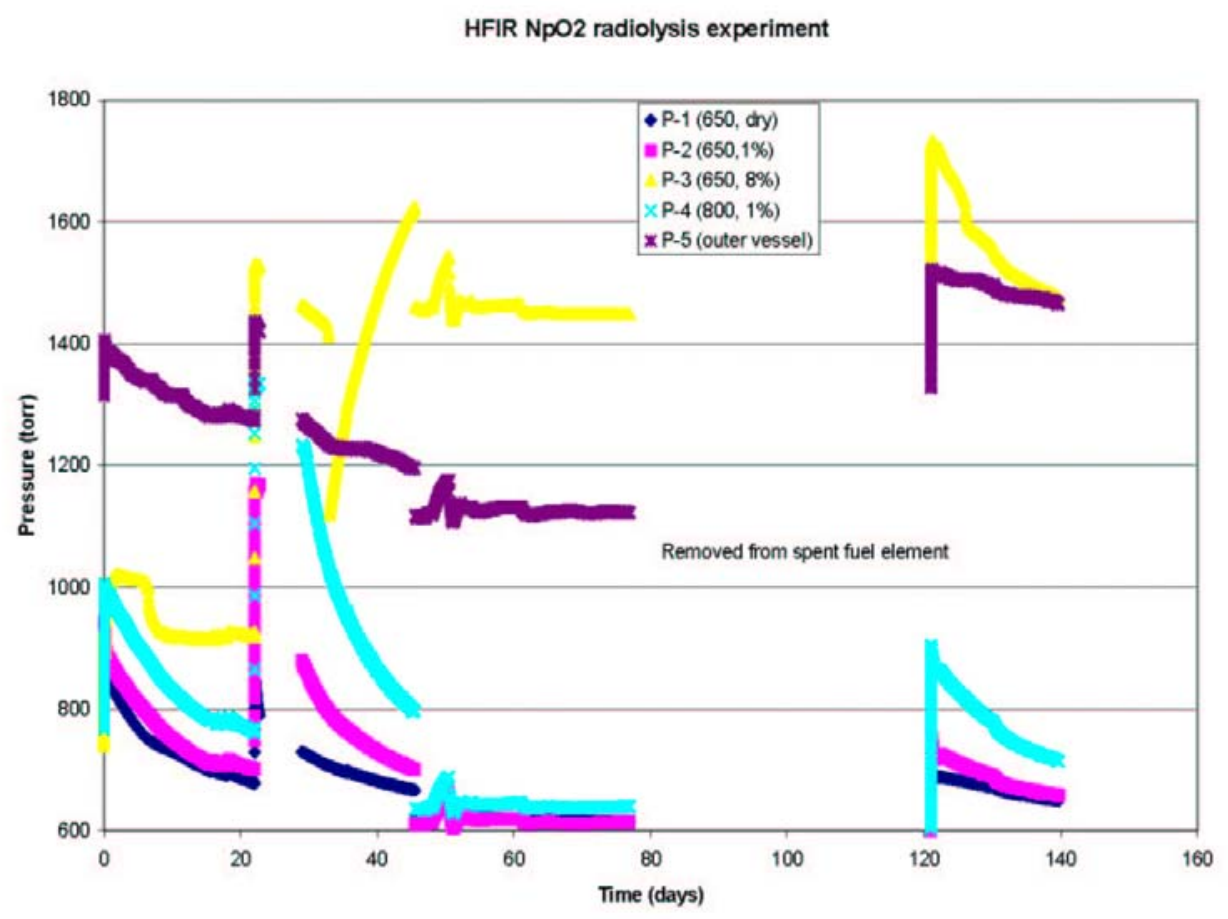

Fig. 9. Gas pressure versus time for $\mathrm{NpO}_{2}$ irradiated by a spent HFIR core.

\subsubsection{Alpha Radiolysis Experiments}

Gas pressure data from the alpha radiolysis experiments are depicted in Fig. 10. In this experiment, Tube 3 with 8 wt $\%$ water, showed a significant gas overpressure - nearly 85 psi. 


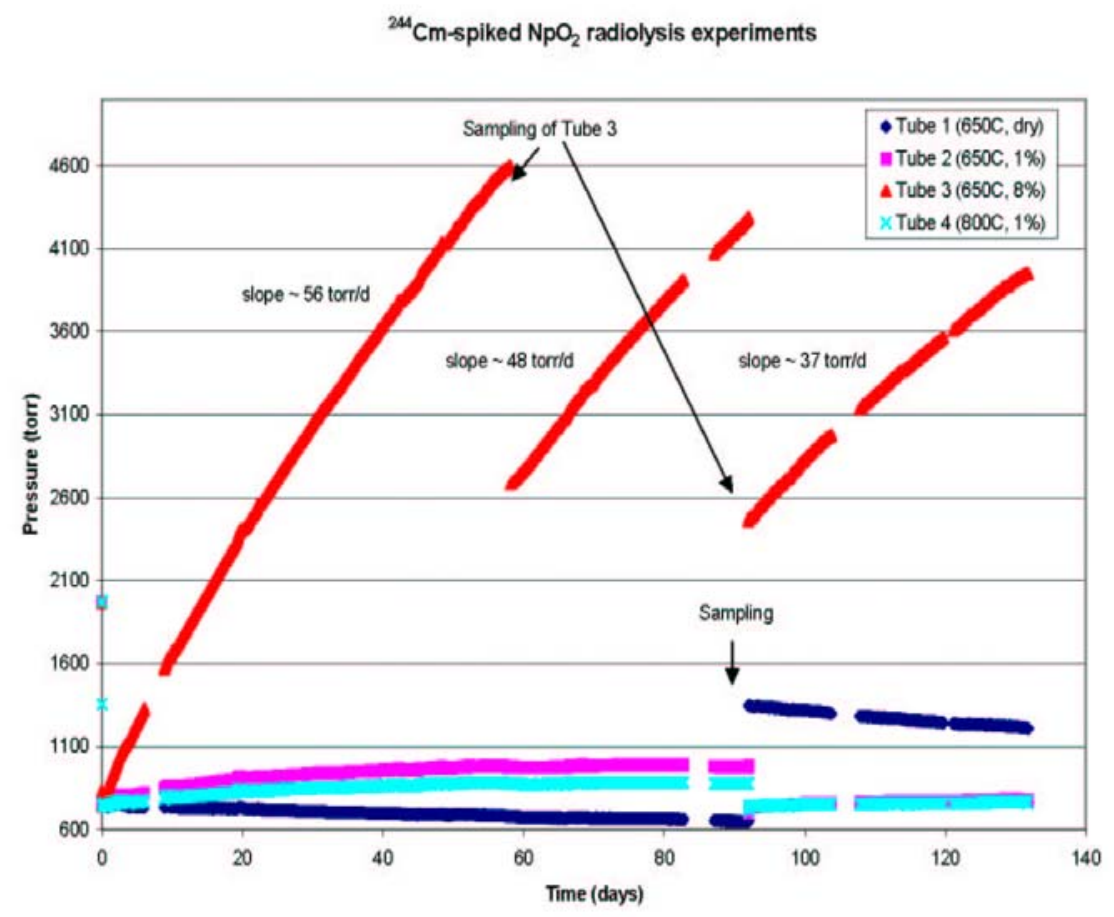

Fig. 10. Gas pressure as a function of time for ${ }^{244} \mathrm{Cm}$-spiked radiolysis experiments.

The increase in gas pressure was significant enough to warrant pulling a gas sample to reduce the pressure. Gas analysis observed that $\mathrm{H}_{2}$ was produced.

The experiment will continue as long as practical or until the pressure reaches a steady state.

\subsubsection{Storage of $\mathrm{NpO}_{2}$ in Oak Ridge}

During this fiscal year, a new option for $\mathrm{NpO}_{2}$ storage in Oak Ridge was identified. The new option, depicted in the flowsheet shown in Fig. 11, is the Y-12 Plant. Y-12 currently stores highly enriched uranium (HEU) as well as weapons components. The additional storage of $\mathrm{NpO}_{2}$ at $\mathrm{Y}-12$ would only be a small increment compared to the current storage missions at $\mathrm{Y}-12$.

The current plans are that SRS will place three crimp-sealed cans, with the configuration shown in Fig. 5, inside of a 35-gal 9975 container. The drums will be transported to ORR where the material will be left in the cans in the shipping package and stored in the materials in a special area at the Y-12 plant. 


\section{Approach for ${ }^{238} \mathrm{Pu}$ Production and Recovery}

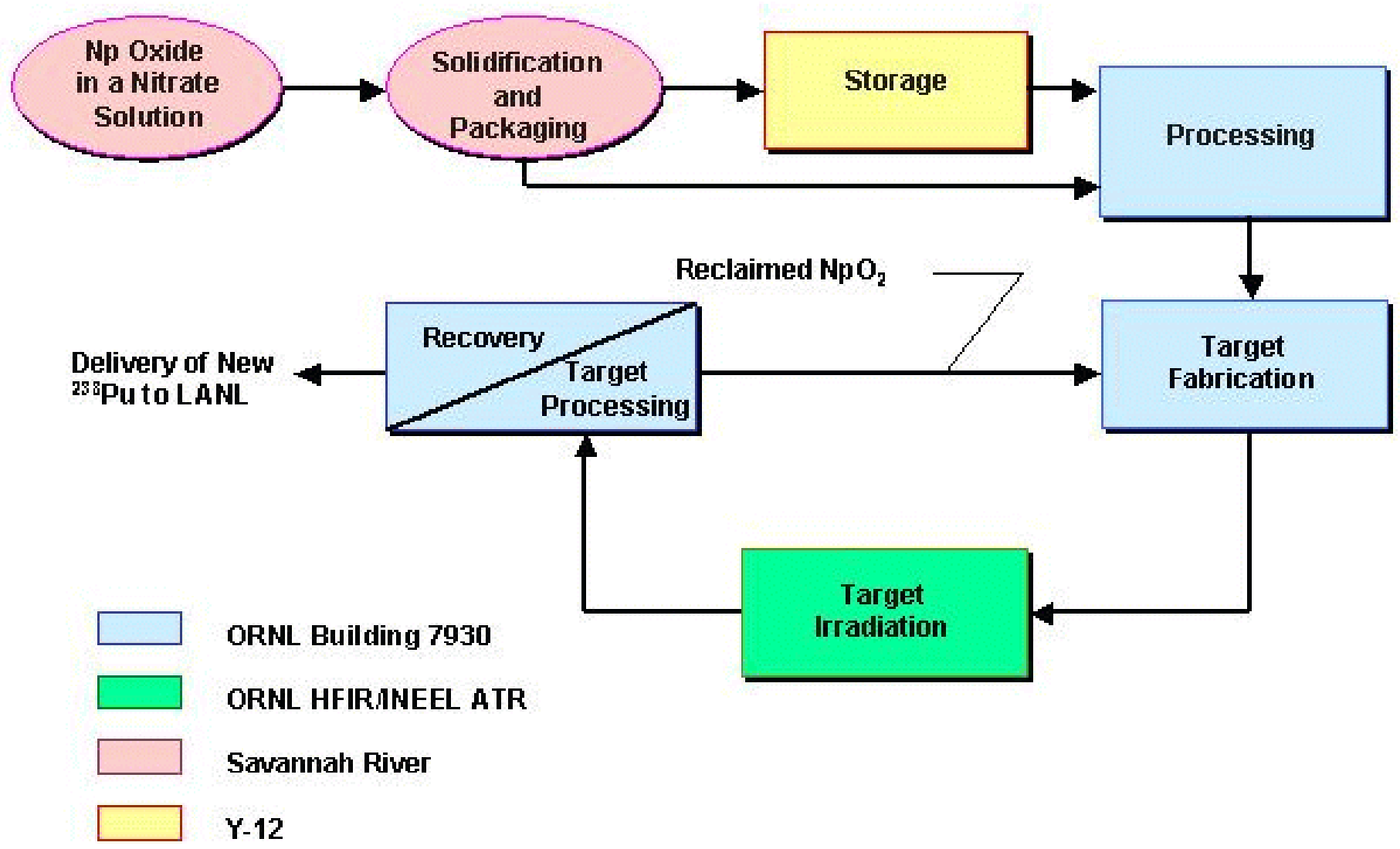

Fig. 11. Diagram depicting proposed functions of various DOE sites in supporting ${ }^{236} \mathrm{Pu}$ production.

ORNL DUNG ge-68DSEII

The storage requirements are being developed in conjunction with Y-12 and SRS. Currently the storage requirements are as follows:

Radiation dose rate at the surface of the drum $<5 \mathrm{mrem} / \mathrm{hr}$.

Radiation dose rate at one foot from the surface of the container $<2 \mathrm{mrem} / \mathrm{hr}$.

All drums capable of shipment to ORNL.

Criticality safety-TBD. 
At the end of the fiscal year, Y-12 had received a draft shipper receiver agreement for neptunium transfer that will be used to help define storage requirements. Facility Safety staff at Y-12 began reviewing current safety documents to determine how to begin analyzing the storage of $\mathrm{NpO}_{2}$.

Ultimately, transfer of $\mathrm{NpO}_{2}$ from SRS to Y-12 is dependent on the safeguards and security requirements which apply to the total amount of material per shipment. Currently, SRS is examining methods to ship as much as possible for each shipment which will require a safe, secure trailer (SST) for shipment. The schedule will depend on the ability to schedule a carrier, and the ability to receive the carrier at the storage site.

Those options are discussed below:

The drums will be sent on a dedicated SST, and SRS estimates about 25 drums could be shipped on each SST for a total of $\sim 5$ single trailer shipments.

If the demand for SSTs is significant, SRS may need to piggy back with other shipments between SRS and the Oak Ridge Site. In this case, an estimated 5-10 drums may be sent on each SST shipment depending on availability of room in the SST.

The transfer rate between Y-12 and ORNL depends on the overall ${ }^{238} \mathrm{Pu}$ production rate. At this point, the planning basis for ${ }^{238} \mathrm{Pu}$ production is $2-5 \mathrm{~kg} / \mathrm{yr}$. In addition, we expect the first few years of the project to require more transfers in order to ramp up to production levels. We anticipate a cycle time of $\sim 3$ yrs between target fabrication, target irradiation, target cooling, and chemical processing. The recycle neptunium is likely to be tied up somewhere in the overall material process flow for about 2-3 years so we are estimating a need for nearly $100 \mathrm{~kg}$ of ${ }^{237} \mathrm{~Np}$ in the first one to two years in order to fill the pipeline with fresh targets, irradiated targets, etc. None the less, the analysis assumed $100 \mathrm{~kg}$ delivered to ORNL during the first year. Subsequent years will require about $8 \mathrm{~kg}$ of fresh $\mathrm{NpO}_{2}$ as makeup feed for 2-3 shipments per year between Y-12 and ORNL.

The shielding present in the 9975 drum was found to be adequate for the quantities of $\mathrm{NpO}_{2}$ present. 
INTERNAL DISTRIBUTION

1. E. P. George

2. J. S. Ivey

3. J. F. King

4. C. G. McKamey

5-7. J. P. Moore

8. E. K. Ohriner
9. G. R. Romanoski

10. G. B. Ulrich

11. M. C. Vance

12. R. M. Wham

13. Laboratory Records

\section{EXTERNAL DISTRIBUTION}

14-20. U. S. DEPARTMENT OF ENERGY, NE-50/Germantown Building, 1000 Independence Avenue, SW, Washington, District of Columbia 20585-1290
J. Dowicki
L. L. Rutger
R. R. Furlong
E. J. Wahlquist
A. S. Mehner
R. L. Wiley
R. C. Raczynski

21. DEPARTMENT OF ENERGY, Albuquerque Field Office, P.O. Box 5400, Albuquerque, NM 87115

R. L. Holton

22-23. DEPARTMENT OF ENERGY, Oak Ridge Operations Office, Bldg. 4500N, Oak Ridge, TN 37831

L. W. Boyd, Mail Stop 6390

S. R. Martin, Jr., Mail Stop 6269

24. DEPARTMENT OF ENERGY, Los Alamos Area Office, 528 35th Street, Los Alamos, NM 87544

R. J. Valdez

25. DEPARTMENT OF ENERGY, Savannah River Operations Office, Bldg. 703F, P.O. Box A, Aiken, SC 29802

S. W. McAlhaney

26. DEPARTMENT OF ENERGY, Miamisburg Office, P.O. Box 66, Miamisburg, OH 45343

T. A. Frazier

27. BABCOCK AND WILCOX OF OHIO, INC., 1 Mound Road, Miamisburg, OH 45343-3000

D. M. Gabriel

28. LOCKHEED MARTIN ASTRONAUTICS, P.O. Box 8555, Philadelphia, PA 19101

R. M. Reinstrom 
29. LOS ALAMOS NATIONAL LABORATORY, P.O. Box 1663, NMT-9, MS E502, Los Alamos, NM 87545

E. M. Foltyn

30. TETRA TECH NUS INC., 20251 Century Blvd., Suite 200, Germantown, MD 20874

B. W. Bartram

31-32. ORBITAL SCIENCES CORPORATION, INC., 20030 Century Blvd., Suite 102, Germantown, MD 20874

R. T. Carpenter

E. A. Skrabek

33. PHILLIPS LABORATORY, Kirtland Air Force Base, AFRL/VSDV, 3550 Aberdeen Avenue SE, NM 87117

C. Mayberry

34. TEXAS A\&M UNIVERSITY, Center for Space Power, Mail Stop 3118, College Station, TX 77843

M. J. Schuller

35. WESTINGHOUSE ADVANCED TECHNOLOGY BUSINESS AREA, 1310 Beulah Road, Building 401, 2nd Floor, Room 2B01, Pittsburgh, PA 15235

M. O. Smith 